\title{
Authentic Leadership and Openness to Change in Pakistani Service Industry: The Mediating Role of Trust and Transparent Communication
}

\author{
Abdul Basit \\ Research Scholar \\ Karachi University Business School, University of Karachi, Pakistan \\ Dr. Danish Ahmed Siddiqui \\ Associate Professor \\ Karachi University Business School, University of Karachi, Pakistan
}

Received: Jul. 6, 2020 Accepted: Sept. 4, 2020 Online published: Sept. 7, 2020

doi:10.5296/ijhrs.v10i3.17318ＵRL: https://doi.org/10.5296/ijhrs.v10i3.17318

\begin{abstract}
Organizations to engage in strategic change initiatives to remain competitive. Leadership is the top determinant of successful change. This study investigated the factor affecting the employee's openness to change during process of change and how leadership affects that. We proposed a theoretical framework, modifying (Yue, Men, \& Ferguson, 2019) by incorporating Authentic in place of transformational Leadership. We hypothesized that authentic leadership affect organisational trust during change both directly, as well as by inducing transparent communication. Trust would in turn positively affect openness to change. Authentic leadership included 1. Self-Awareness, 2. Relational Transparency, 3. Balanced Processing, and 4. Internalized Moral Perspective, dimensions. Whereas, transparent communication consisted of 1. Participation, 2. Substantiality, 3. Accountability, Factors. Empirical validity was established by conducting a survey using close ended questionnaire. Data was collected from 310 employees working across different service industry in Karachi, and analyzed using confirmatory factor analysis and structured equation modeling. The finding revealed that transparent communication and authentic leadership have significance direct and indirect relationship with employees' openness to change. Organizational trust has significant relationship with employees' openness to change during change process. However Authentic leader has weak direct relation with transparent communication and there is no significance
\end{abstract}


relationship between authentic leadership and trust with mediating role of transparent communication. However, trust significantly mediate all the factors of authentic leadership except Self-Awareness, and Openness to Change. Similarly, trust also mediated Substantiality, and Accountability factors of communication, and openness. Lastly, substantiality also offered a partial mediatory role between authentic leadership and trust.

Keywords: authentic leadership, transparent communication, organizational trust during change, employee openness to change, Pakistan

\section{Introduction}

\subsection{Background to the Study}

In today competitive business environment managing change is become pivotal for organization growth, success and survival. In order to get survive in this competitive world and achieve competitive advantage, organization continuously adopting new technology, reengineering organizational structure and downsizing. In recent era jobs are became more complex, employees are required to adopt behavior and attitude that beyond the job description which result in employees openness to change during the change. Unfortunately, uncertainty about the future, to deal with change has become difficult for individual as well as organization. Many companies are developing strategies to cope with change. It has become a norm for organizations to engage in strategic change initiatives to remain competitive (Johansson \& Heide, 2008) It has become way of existence for organization to be involved and developing strategies. But every organization change come with its complexities. These complexities can lead to variety of factor which include higher turnover, low satisfaction, productivity and frustration. Which result in failure of change initiative. According to (Burns, 2000) which states that change initiative fail by the frequency of (40\%-70\%)There are multiple reason which can result in failure of change initiative that one of the most prominent is lack of support from leadership, Lack of adequate resources, Lack of leadership skills and lack of understanding how change will actually impact employ.

Leadership plays a pivotal role influencing subordinate to get desired behavior and attitude during change process and to cope within societal and organizational problems. According to (Gill, 2002) American Management Association survey demonstrate that leadership is prominent characteristic to achieve successful change and ensued by factor followed by corporate values, and communication. There are several leadership style that can impact employees openness to change that comprise transformational leadership transaction leadership and authentic leadership. The authentic leadership approach is more related to leader's authenticity or being honest and faithful to the subordinate. They are not afraid of showing their emotion or being ethical or transparent to employs. According to (Avolio, Gardner, Walumbwa, Luthans, \& May, 2004) Authentic leader are highly authentic that they are aware of their believe and who they are, interaction is based in transparency and act on their value and believe. Researcher suggest several learning and motivational mechanisms are activated by authentic leadership during change which result in effective implementation of change. This research processes that follower strong and important attitudes can be influenced by authentic leadership related to change and cynicism about change (Bommer, 
Rich, \& Rubin, 2005; Dean, Brandes, \& Dharwadkar, 1998; Reichers, Wanous, \& Austin, 1997; Stanley, Meyer, \& Topolnytsky, 2005)

Authentic leaders are

i. self-awareness know their own strengths and weaknesses and they build close interactions with their followers

ii. Relational transparency: they share information with subordinate and developed trust

iii. balanced information processing: integrate employees' relevant feedback and all relevant information in making decisions

iv. Internalized moral perspective: incorporate a positive moral perspective that guides their leadership behaviors, such as honesty, fairness, and accountability (Walumbwa, Avolio, Gardner, \& Wernsing, 2008; Yukl, 2006)

This study also examines communication impact on employees openness to change and reveal how effective communication in organization is pivotal for organization change, crafting transparency and giving voice to employees to be involved in decision making and brainstorming. Strategic internal communication plays a vital role in change management. Absence of strategic internal communication change, initiative eventually fails. (Elving, 2005). Lack of internal communication result in ambiguity, uncertainly and lack of trust between employs and organization. Which can comprise of several factors including lack of feedback, one way of flow of information but at the same time effective and transparent communication can result in positive outcome including employees trust, motivation and self-confidence. Public relations scholars have consistently found that various positive employee outcomes are achieved by transparent communication and which contributes to several positive employee outcomes including employee trust (Jiang \& Luo, 2018; Rawlins, 2008). Due to emerging consideration of implementing change in organization, the significance of transparent communication is emerged. Transparent Communication is being a key concern for all stakeholder. Employ, manager and shareholder. From the perspective of employees transparent communication not only eradicate uncertainty but build trust and confidence among follower and leaders. Building strong relationship with employees is necessary because the only source of productivity is employees and their faith toward organization will increased will lead them to openness to change. Trust is fundamental building block of an organization and its capability to make or break change initiative strategy. Trust during the change process result in high moral, absence of resistance increase loyalty and its paves the way for sharing new idea which result in increased efficiency and productivity. Trust is considered and proposed factor in organization performance and success (Currall \& Epstein, 2003). Prior research has consciously linked the positive relationship of trust with employees and organization outcome, such as work performance increased by the employs (Brown, Gray, McHardy, \& Taylor, 2015).Communication and effective leadership 
potentially create employees organization trust which in result can mitigate their psychological stress and uncertainty and pave the way for change acceptance (Rousseau \& Tijoriwala, 1999).

In the literature review the study will focus on key concept authentic leadership employees openness to change transparent communication and organizational trust during change. In the hypothesized model the relationship of these latent variable will be tested and validated.

\subsection{Problem Statement}

Follower's psychological capacities are associated with authentic leadership (Gardner, Avolio, Luthans, \& May, 2005; Woolley, Caza, \& Levy, 2011) And change commitment are likely to be influenced by psychological capacities (Shin, Taylor, \& Seo, 2012). Change is become the emerging topic in business word. Failure to change can result in devastating effect on organization and as well as employ. The consequences of Failure in change may be the result of weak leadership skill or avoiding the desires of employees during the change process.

The role of employees openness of change have gained attention in recent year among business researchers. The changes in companies are inevitable. Employees openness to changes is crucial for organization survival and existence which can lead to companies to one state to higher state if relevant strategies and leadership style are established.

Employees Openness to change in this research is vital for the services industries operating in Pakistan. Behavior research are mostly conducting in western countries. Employees openness to change is crucial for organization growth and survival. In recent years large inflow of investment and interest of multiple national companies to commencing business in Pakistan leads to series of merger, acquisition and partnership. During this process employees face new challenges and leadership transition crisis. This research also demonstrates factors authentic leadership and transparent communication affecting the employees openness to change. In Pakistan leadership considered to be paternalistic in nature and communication in office space considered to be one way. The role of authentic leader and transparent communication is yet to be discovered during change in this part of the world. The genuine leadership and transparent communication of employees and organization can lead to survival and existence of company in rapidly changing external environment.

\subsection{Gap Analysis}

Research has consistently shown the positive impact of transformational leadership on employee outcomes across situations including organizational change (Herold, Fedor, Caldwell, \& Liu, 2008; Paulsen, Callan, Ayoko, \& Saunders, 2013). Change initiative certainly fails when lack strategic internal communication (Elving, 2005). Leader's pressure is increased by organizational changes who play pivotal part in change implementation (Pawar \& Eastman, 1997). Another major factor, which emerged from previous research, that impacts change management, is strategic internal communication. Prior research also shows that quality internal communication supposedly reduces perceived uncertainty related to the change and decreases employees' resistance to change (Allen, Jimmiesons, Bordia, \& Irmer, 
2007; Elving, 2005) Public relations scholars have consistently found that transparent communication contributes to various positive employee outcomes, such as employee trust (Jiang \& Luo, 2018; Rawlins, 2008), corporate reputation (Men, 2014) and employee-organization relationships (Men \& Stacks, 2014)Previous study found out that, trust also results from effective internal communication and in turn affects employee behaviors and overall organizational outcomes (Shockley-Zalabak \& Ellis, 2006) (Devos, Buelens, \& Bouckenooghe, 2007; Ertürk, 2008). In organization, several factor can also influence level of trust that include leadership behavior of supervisor and managers (Men, 2014; Men, 2015; Men \& Stacks, 2014) and communication in organization (Mishra, Boynton, \& Mishra, 2014).

These factors were studied in isolation, and the link between leadership, communication, trust and openness to change was not established. To fully delineate how leadership and strategic internal communication influence employee openness to change, (Yue, Men, \& Ferguson, 2019) examines how transformational leadership and perceived transparent communication may interplay to influence employee openness to change through fostering employee trust during an organizational change event. However, very few studies focused on authentic leadership impacting trust, openness to change and authentic leadership impact on transparent communication. For example, pervious research also found out that authentic leader can build desired attitude that influence behavior toward change (Bommer, Rich, \& Rubin, 2005; Dean, Brandes, \& Dharwadkar, 1998; Reichers, Wanous, \& Austin, 1997; Stanley, Meyer, \& Topolnytsky, 2005). Conversely there is no study to identify relationship of these variable collectively meanwhile there has not been any study about authentic leadership impact employees openness to change via mediating role of trust and transparent commination. For this, we proposed a theoretical framework, modifying (Yue, Men, \& Ferguson, 2019) by incorporating Authentic in place of transformational Leadership. We hypothesized that authentic leadership affect organizational trust during change both directly, as well as by inducing transparent communication. Moreover, no such research was conducted in context of Pakistan. Mostly behavioral research are conducted in first world countries. Pakistani organization are facing challenges and difficulties in implementing changes specifically in employees behavior change because of paternalistic culture and lack of trust between employs and leaders. This study fills the gap by proposing model that describe transparent communication by sub variable (accountability, participation Substantiality) and authentic leader (self-awareness participation, internal moral perspective relationship transparency) mediating role of trust influencing employees openness to change in services industry in Pakistan. Furthermore, also identify the sub variable that leads to effective transparent communication and building authentic leadership competencies.

\subsection{Research Objective}

This present study demonstrates how several organizational factor can relate to employees openness to change such as leadership style authentic leadership, transparent organizational communication, and organizational trust during change. More specifically, this research explored the role and relationship between authentic leadership transparent communications, employees openness to change and with mediating role of organizational trust during change. 
We hypothesized that authentic leadership affect organizational trust during change both directly, as well as by inducing transparent communication. Trust would in turn positively affect openness to change. Authentic leadership included 1. Self-Awareness, 2. Relational Transparency, 3. Balanced Processing, and 4. Internalized Moral Perspective, dimensions. Whereas, transparent communication consisted of 1. Participation, 2. Substantiality, 3. Accountability, Factors.

\subsection{Research Questions}

1. What is the relationship between authentic leadership and employees openness to change?

2. What is the relationship between transparent communication and employees openness to change?

3. What is the relationship between authentic leadership and transparent communication?

4. What is the relationship between organization trusts and employees openness to change?

5. What is the relationship between authentic leadership and organizational trust?

6. What is the relationship between transparent communication and organizational trust?

\subsection{Significance of the Study}

This research paves the way for dealing with changes in more effective manner and provide analytical tool for resolving employees behavior aspect of openness to change. There has not been any research to study the relationship of authentic leadership, transparent communication and openness to change with mediating role of organization trust. The result of this study lead to practical implication. It aids to organization success and lead organization to reconsider leader's competency from transaction and transformational leadership to authentic leadership who build honest relationship with followers. Which leads to self-confidence integrity and trust. That result in this leadership is more effective in workplace environment where people can give their maximum potential.

The importance of employee openness to change is valued by societal and environmental trend. It deals with behavior aspect of employ, the authentic leadership and transparent communication lead to mitigate the negative behavior of employees by providing organization trust. This study helps into increase physiological capital which leads to building trust and readiness of employees toward change whereas the study will help rapidly changing industries (Technology companies) who face resistance in employees openness to change, the finding of this research will have positive and significant implication on organization during change and provide direction for future researcher.

Furthermore, the finding will help the HR manager to develop competency based recruitment and training that comprise authentic leadership skill and communication transparency skill. It will assist Pakistani companies to effectively manage change and train leader with required competency as authentic leader which help organization to get sustainable competitive 
advantage. It will help the manager to make communication framework that encourage feedback regarding organization decision during change

\subsection{Scope of Study}

Openness to change by authentic leadership and transparent communication relationship is new term to management of organization. Limited empirical research has been done on these construct. The research is based in Karachi which focuses services industries. Due limited time the questionnaire collected randomly sample size of 310.This study is important in identification of utmost variable and strategic trend that impact employees openness to change.

\section{Literature Review}

The Organizational change is instigated by a "relevant environmental shift," organizational responses to accommodate new policies, processes, values, and staff. (Porras \& Silvers, 1991; Seeger, Ulmer, Novak, \& Sellnow, 2005).The comprehensive range of topic is included in the change initiative which comprised of Merger, acquisition, installing new technology, restructuring of organization .layoff and downsizing and leadership (Beck, Brüderl, \& Woywode, 2008).It is argued changes fail due to their implantation issue not because of the inherent flaws (Choi, 2011).

The research gradually shifted toward the diverse approaches of change implementation to examine "how change recipients react of organization change" (Oreg, Vakola, \& Armenakis, 2011). Employs play a pivotal role in the implementation of a successful change initiative, being acknowledged by both management practices and scholarship (Oreg, Vakola, \& Armenakis, 2011; Cummings \& Worley, 2005; Fugate, Prussia, \& Kinicki, 2012) .The literature of organization change is copious describing and investigating various employees response to the change initiative for example openness to change, commitment to change, readiness to change resistance to change, cynicism about change (Bouckenooghe, 2010; Jimmieson, Peach, \& White, 2008). The researcher should focus on the condition which fosters personnel support for change. (Choi, 2011). This article proposes that authentic leadership can affect followers' important, popular attitudes and beliefs about change namely cynicism about change (Bommer, Rich, \& Rubin, 2005; Dean, Brandes, \& Dharwadkar, 1998; Reichers, Wanous, \& Austin, 1997; Stanley, Meyer, \& Topolnytsky, 2005) commitment to change (Herscovitch \& Meyer, 2002) .Though authentic leadership has been developed in Western context (Gardner, Avolio, Luthans, \& May, 2005). Its relevance to Pakistani culture has been proved in a recent study in which the authors applying a life story approach reviewed interviews of 14 leaders from South Asia including Pakistan (Khilji, Keilson, Shakir, $\&$ Shrestha, 2015). The authors further posit that keeping in view the problems faced by Pakistani organizations attributed to lack of leadership, the concept of authentic leadership may provide avenues to foster positive organizational behaviors in followers (p. 18).

Communication play a substantial role in process of change and it's echoed in strategic internal communication between organization and its employ. Role of communication is stressed by (Ford \& Ford, 1995) Who expressed, "change is created, sustained, and managed 
in and by communication" (p. 560).Strategic internal communication strengthen organization strategic value and objective, different contribution can be made by communication. The contribution of strategic internal communication has been seen in different aspect of the change initiative, can strengthen the objective and value of an organization (Barrett, 2002; Neill, 2018) Whereas Articulate shared change visions (Fairhurst, 1993; Luo \& Jiang, 2014) Build emotional support during the change (Luo \& Jiang, 2014) And mutual understanding is enhanced between decision-makers key users and implementers (Lewis, 1997).

Organization changes studies are abundant in both psychology and management (Oreg, Vakola, \& Armenakis, 2011). The role of communication is pivotal in change initiative however it is surprising to see a lack of perspective on public relations and an attitude to communication regarding organizational change (Johansson \& Heide, 2008)

It explains and fill the gap between the hypothesized model that join employees openness to change with transparent communication and authentic leader with mediating role trust. Below we conceptualize two main antecedents factor which comprised authentic leadership and transparent communication and its impact on employees openness to change and build trust directly and indirectly impact employees openness to change

\section{Theoretical Framework}

\subsection{Openness to Change}

The Result of prior literature has demonstrated that large scale organization change are often disappointing. (Beer \& Nohria, 2000) .Employs are not passive recipients in change initiative rather they participate actively in the Change process (Augustsson, Richter, Hasson, \& von Thiele Schwarz, 2017). Change process and the outcome are considerably affected by employees attitude behavior and belief (Nielsen \& Randall, 2013). Such responses include openness to change of employees is "necessary initial condition for successful planned change" (Miller, Johnson, \& Grau, 1994, pp. 59-80). Whereas openness to change "the most important element of organizational culture that leaders should look to build" in the process of change (Ertürk, 2008, p. 463). In contrast absence of behavior toward openness change is "an ominous sign" the planned changed may be predicted as a failure (Miller, Johnson, \& Grau, 1994, p. 66). Although openness to change can be characterized by traits including flexibility and novelty (Fugate \& Kinicki, 2008). Specific organizational change is mainly determined by situational variable and other variables such as the perception of an individual, evaluation and experience by change whereas openness to change made up two elements including positive impact towards the change outcomes and followed by proposed change initiative are supported willingly (Miller, Johnson, \& Grau, 1994; Wanberg \& Banas, 2000).Welcoming attitude toward the change of employees is reflected positively and believing that they are beneficiary of change. It also demands openness to change, only tap on these employees' behavioral intention and psychological prepared to change (Augustsson, Richter, Hasson, \& von Thiele Schwarz, 2017). Instead of actual behavioral support of change and In line with that, the theory of planned behavior (Augustsson, Richter, Hasson, \& von Thiele Schwarz, 2017). Which state that intention to executes a certain behavior paves the way to guides the following behavior (Ajzen, 1991).As recognized in the literature the 
readiness of change can be precursor by openness to change (Axtell, et al., 2002; Devos, Buelens, \& Bouckenooghe, 2007). Which leads to job satisfaction and low intention to leave a job (Wanberg \& Banas, 2000).

\subsection{Authentic Leadership}

The core of Authenticity is to understand accept and bring to oneself (Harter, 2002). Authentic leadership has gained a reputation among the business community in specifically in leadership theory and framework for leadership development propelled largely by (George, 2003). Authentic leadership is describe as "a process that draws from both positive psychological capacities and a highly developed organizational context, which results in both greater self-awareness and self-regulated positive behaviors on the part of leaders and associates, fostering positive self-development (Luthans \& Avolio, 2003)”. The immense demand for authentic leadership is due to its focus on leaders and characteristics like genuineness and authenticity in leadership. Scholars have explained authentic leadership in several ways. Each definition has its own observation and with different prominence (Chan, Hannah, \& Gardner, 2005)

Researchers in the field of communication have recently emphasized the need for integrating authenticity to research and into communications management practice. (Edwards, 2010; Men, 2014; Men, 2015; Men \& Stacks, 2014; Molleda, 2010). In particular, authentic leadership is described as being Specifically, authentic leadership is defined as "a pattern of leader behavior that draws upon and promotes both positive psychological capacities and a positive ethical climate, to foster greater self-awareness, an internalized moral perspective, balanced processing information, and relational transparency on the part of leaders working with coworkers, fostering positive self-development" (Walumbwa, Avolio, Gardner, \& Wernsing, 2008, p. 94). The behavior of authentic leadership is compromised by four dimensions self-awareness, internalized moral perspective, balanced information processing, and relational transparency and which has broad empirical (Bamford, Wong, \& Laschinger, 2013; Valsania, León, Alonso, \& Cantisano, 2012). Authors such as (Spoelstra, Butler, \& Delaney, 2016) believe that leadership "studies are in crisis" to be thoroughly reviewed including its key assumption methods and objective. An authentic leadership is emerging new concept currently is in under development phase. (Gardner, Cogliser, Davis, \& Dickens, 2011). Leaders play a key role in changing employees behavior which result in smooth tranistion of change and employees become more commited and loyal to their orgainzation.

\subsubsection{Self-awareness}

Self-awareness is explained as the leader's ability to understand his or her strength weakness value and motives, denotes the extent to which a leader understands his or her strengths, weakness, values and motives and the recognition of how others perceive their leadership (Avolio, Gardner, Walumbwa, Luthans, \& May, 2004).

\subsubsection{Internalized Moral Perspective}

Internalized moral perspective includes behavior that is driven by internal moral principles and values, rather than by external forces such as peer, society and organization (Gardner, 
Avolio, Luthans, \& May, 2005).furthermore Internalized moral perspective defined as, leader's inner drive to achieve consistency between his/her values and actions (Avolio, Gardner, Walumbwa, Luthans, \& May, 2004)

\subsubsection{Balanced Processing}

Balanced processing information define as before making decision, critically analysis all the relevant information and entreating even a challenging input or feedback. (Walumbwa, Avolio, Gardner, \& Wernsing, 2008). Before making a decisions leaders consider all relevant information and point of view of the stake holders. It makes their actions well planned and well thought-out. (Gardner, Avolio, Luthans, \& May, 2005).

\subsubsection{Relational Transparency}

Relational transparency mainly deals with the sharing information openly and realizing and building openness to others by sharing their true ideas (Avolio, Walumbwa, \& Weber, 2009) . Relational transparency defined as to authentic, leader and follower relationship where both share information in transparenernt manner (Walumbwa, Wang, Wang, Schaubroeck, \& Avolio, 2010)

\section{Authentic leadership and employee openness to change.}

According to (Luthans \& Avolio, 2003) Authentic leadership is 'a process that draws from both positive psychological capacities and a highly developed organizational context, which results in both greater self-awareness and self-regulated positive behaviors on the part of leaders and associates and fostering positive self-development'. Taking above stand the leaders who is self-aware knows his capabilities skill and can identify the gap of trust between subordinate and manager and lead to desired positive behavior to openness to change .Leader who are internalized moral perspective are continuously aiming to achieve consistency in his word and action. Furthermore leaders emphasize on transparent communication, provide others with the assumptions, values, and information upon which employ career can be impacted, which in return build confidence, and openness to change. Leaders build relationship transparency, communication demonstrate sharing point of view to employ openly and no attempt to hide any information. Which leads to build desired behavior to openness to change. Balance processing refers leaders consider all relevant information and point of view of the stake holders specifically during change processes. Authenticity may enhance psychological safety as a result of balanced processing by the leader, that is important for dialogue and learning (Edmondson, 1999). Hence, based on above discussion, following hypothesis are proposed

H1.1: Relational Transparency during the change is significantly and positively influence with employee openness to change.

H1.2: Internalized Moral Perspective during the change is significantly and positively influence with employee openness to change

H1.3: Substantiality during the change is significantly and positively influence with 
employee openness to change

\section{H1.4: Balanced Processing during the change is significantly and positively influence with employee openness to change}

\subsection{Employee Organizational Trust}

Broadly defined trust as "a psychological state comprising the intention to accept vulnerability based upon positive expectations of the intentions or behavior of another" (Rousseau, Sitkin, Burt, \& Camerer, 1998, p. 395). The discussion of trust has extensively been discussed in relational, organizational and societal level (Cook \& Schilke, 2010) and Throughout multiple disciplines such as disciplines of marketing, management, economics, political science, psychology, information systems communication and law (Schoorman, Mayer, \& Davis, 2007; Yang \& Lim, 2009) Scholars from earlier time defined trust from trait perspective and individual characteristics examined, that could predict their trusting disposition (e.g, Interpersonal Trust Scale). (Rotter, 1967).Newer debates, however, have emerged with emphasizing trust one of the key aspect of organizational relationship (Hon \& Grunig, 1999; Mayer, Davis, \& Schoorman, 1995; McKnight, Choudhury, \& Kacmar, 2002; Shockley-Zalabak \& Ellis, 2006). Trust has been defined as "the willingness of a party to be vulnerable to the actions of another party" (Mayer, Davis, \& Schoorman, 1995, p. 712) And then, "the decision to rely on another party under a condition of risk" (Currall \& Epstein, 2003).Relationship trust has two central components including reliance (dependency) and risk (vulnerability) This definition reveals two central components of relational trust: reliance (dependency) and risk (vulnerability), that are embedded in public-organizational relations (Currall \& Epstein, 2003; Rawlins, 2008). The organizations own more power than the public resulting public in a vulnerable position while handling their relationship with the organization. Public suffer from risk and losses if the organization become prove to be untrustworthy. Reliance describe as positive expectation public collectively cast on the organization and, trusting in the organization that it will fulfill its promise and expected to behave with benevolence, honesty, reliability, and integrity " (Currall \& Epstein, 2003; Yang $\&$ Lim, 2009). The same goes for public relations scholars, such as (Hon \& Grunig, 1999).Trust described as “one party's level of confidence in and willingness to open oneself to the other party" (p. 2). Three underlying dimensions of trust were identified (1) integrity, that states that company is fair and just; (2) dependability, the assurance on company stated position, will do what it says it will do; and (3) competence, the belief that the capacity of company to do what it says it will do $(1999$, p. 3). Based on definitions provided by the (Rawlins, 2008) and (Hon \& Grunig, 1999). This study provides definition Employees trust on the organization is deemed to be vulnerable by the organization action and believe on organizational integrity dependable and competent whereas trust with other 5 dimensions of OPR has been validated furthermore applied in various studies of public relation. Which base that trust is a pivotal indicator of organization public relationship ( $\mathrm{Ki} \& \mathrm{Hon}, 2007$ ). Furthermore, relational trust is outcomes of OPR and organizational reputation has been associated with the relational trust (Yang, S U, 2007), whereas result in positive public attitude and behavioral intention (Ki \& Hon, 2007) public engagement (Men \& Tsai, 2016).And including positive communication behaviors of employees. (Kang \& Sung, 
2017).But how Organization resources could be utilized by the organization, the resources such as leadership and internal communication to build organizational trust during the rapid change. It's yet to be explained.

From the internal perspective Employs trust their employer is determined by their cooperation productivity relationship and communication with the organization (Rawlins, 2008).An organization must build trust with employees specifically during the changing environment. it's said to believe that trusting employees demonstrate their trust aligns with the organization, prior research demonstrated that the success of change initiative in the organization is based on employs and managers trust relationship, wherein management employees attitude toward the change can be built by trust (Devos, Buelens, \& Bouckenooghe, 2007; Ertürk, 2008). Meanwhile, the decrease in the perception of the legitimacy of change and less readiness for the change can be the result of a lack of trust. Also, stronger behavioral resistance to change (Oreg, 2006; Rousseau \& Tijoriwala, 1999). Organizations who build trust among their employees pave the way for openness to change following that employees are more vulnerable and accept decisions about change we therefore propose.

H4.1: Employee organizational trust during the change is significantly and positively influence with employee openness to change.

\section{Authentic leadership and employee organizational trust}

As multiple researches have noted, fairness and trustworthiness are closely related constructs and balanced processing demonstrates procedural fairness. (Clapham, Meyer, Caldwell, \& Proctor, 2014). A moral perspective is important in building a sense of legitimacy about a leader's actions and enhances employee respect and commitment. (Beddoes-Jones, 2012). Similarly, Relational transparency is a key element in building trust, and especially in restoring trust when it has eroded (Auger, 2014). Self-awareness is also key to trust building because It helps people to align to their terms with their values, priorities, and personal identity (Showry \& Manasa, 2014). Hence, based on above discussion, following hypothesis are proposed.

H2.1: Balanced Processing during the change is significantly and positively influence employee organizational trust

H2.2: Internalized Moral Perspective during the change is significantly and positively influence employee organizational trust

H2.3: Relational Transparency during the change is significantly and positively influence employee organizational trust

H2.4: Self-Awareness during the change is significantly and positively influence employee organizational trust

\subsection{Transparent Communication}

Without communication, effective leadership cannot work to its fullest capacity and adopting 
transparent internal communication Demonstrate the genuine interest of the organizational leaders to maintain and enhance the relationship with employs following that transparency is opposite of secrecy It is characterized by openness (Rawlins, 2009) Internal communication is characterized by transparent communication (Men \& Stacks, 2014) and the strategic communication has gained that prominence in literature (Jiang \& Luo, 2018)Transparent communication build organizational trust is identified by communication ( (Jiang \& Luo, 2018; Rawlins, 2008) And help in employee-organization relationships enhancement (Men \& Stacks, 2014) Whereas transparency is comprised of three elements informational participatory and accountability transparency and these three "work together but are analytically distinct" (Balkin, J M, 1999, p. 393) . Furthermore, (Rawlins, 2008)and (Jiang \& Men, 2017) they found that There's is a direct relationship between employees trust toward organization and transparent internal communication. Therefore transparent communication cultivate trust and help in overcoming issue of uncertainty. Hence it can be building block to employees openness to change and creating desired behavior to achieve change goal.

\subsubsection{Substantiality}

Informational transparency necessities dissemination of the "truthful, substantial, and useful" information" (Rawlins, 2008, p. 6).That should be noted there is a difference between informational transparency and mere disclosure. Well, confusion is caused by overabundant of information disclosure rather than clarification .whereas in practical life disclosure of information can be claimed by the organization "all legally releasable information" flooded employees with meaningless documents and email (Rawlins, 2009, p. 74)The organization, however, in this case not true neither sincere in their intention to provide key and relevant information. The failure of top management to enforce information transparency will make vague understanding of content, intent and implementation process of the change initiative. Participatory transparency refers to identification of most relevant and concern information to meet employees informational need with involvement of employ. Without listening to employees and their feedback that result in failure of organization to provide significant and relevant information that working employees in organization what and need to know. However, in case, the organization has no true or sincere intention to provide employees with relevant and key information. In the context of a change initiative, and top management's incapacity to implement informational transparency can cloud employees' understanding of the content, purpose, and implementation process of the change initiative.

\subsubsection{Participatory Transparency}

Participatory transparency is an organizational effort to involve employees in identifying the most relevant and concerned information to meet their informational needs. Without consulting employees and asking for their feedback, an organization is not able to provide the substantial and relevant information that employees want and need to know Cotterrell put it this way, Transparency is empowering the receivers of the information "active participation in acquiring, distributing and creating knowledge" (Cotterrell, 1999, p. 419)Meanwhile, management sound constant acquires and ask employees about what information they desire to learn in this context management should create an environment where information is 
accessible to everyone.

\subsubsection{Accountability}

Accountability dimension which concerns transparency refers to the inclusion of positive and negative information which concern about the revelation of both sides of the story. During change initiative, the organization that possesses accountability transparency will have a great understanding of the treats and benefits of the change program. Misrepresentation and rumors can create due to the hiding information which leads to misunderstanding and lack of trust and increase insecurity uncertainty and anxiety (Men \& Bowen, 2017). Well, it is worth noting that in the organization, not all the information are transparent and complete, informing employees about the timeline providing information that enhances their understanding about change initiative that will reduce employees anxiety uncertainty (DiFonzo \& Bordia, 1998) The same approach has been articulated by (Gergs \& Trinczek, 2008). Who pointed that out "withholding information during phases of radical change is one of the worst mistakes in change management" (p. 152). Empirical studies have revealed Trusting relationship between employees and manager can be fostered by employees positive perception of change (Jo \& Shim, 2005)

\section{Authentic leadership and transparent communication}

Self-aware is critical tool for leader to become better leader and improve relationship with colleagues and to manage their emotion. Knowing the strength, weakness and skill have bigger impact on work meanwhile can eradicate barrier in communication. Self-aware leader provides true, relevant both side of information which increases participation of employ. Internalized moral perspective defined as, leader's inner drive to achieve consistency between his/her values and actions (Avolio, Gardner, Walumbwa, Luthans, \& May, 2004). Internal moral perspective leader take decision on their moral standard. These leader are respected trusted by subordinate .furthermore they know the right thing to do and is driven by a concern for ethics and fairness. They convey true information which increase employ information participation and feedback. Balance processing is taking the point of view and voice of employ while making a decision. This increases the information participation in brainstorming and encourage truthful and relevant information. Relational transparency mainly deals with the sharing information openly and realizing and building openness to others by sharing their true ideas (Avolio, Walumbwa, \& Weber, 2009). Leaders who build relationship transparency share information in transparent manner with subordinate, leads to to increase employ participation and accountabality.

H3.1: Balanced Processing during the change is significantly and positively influence Accountability

H3.2: Balanced Processing during the change is significantly and positively influence Participation

H3.3: Balanced Processing during the change is significantly and positively influence Substantiality 


\section{Macrothink}

International Journal of Human Resource Studies ISSN 2162-3058 2020, Vol. 10, No. 3

H3.4: Internalized Moral Perspective during the change is significantly and positively influence Participation

H3.5: Internalized Moral Perspective during the change is significantly and positively influence Accountability

H3.6: Internalized Moral Perspective during the change is significantly and positively influence Substantiality

H3.7: Relational Transparency during the change is significantly and positively influence Participation

H3.8: Relational Transparency during the change is significantly and positively influence Accountability

H3.9: Relational Transparency during the change is significantly and positively influence Substantiality

H3.10: Self-Awareness during the change is significantly and positively influence Participation

H3.11: Self-Awareness during the change is significantly and positively influence Accountability

H3.12: Self-Awareness during the change is significantly and positively influence Substantiality

Transparent communication and employee openness to change.

According to (Waldo, 1977) which sate that participation in decision making is a major paradigm shift for public administrators that can have significant positive benefits. According (Vathsala \& Ruvini, 2012) . Substantiality is giving true information to employees. Trustworthiness is an important factor that facilitates an employee's decision-making process to become vulnerable to organizational top management leaders. It also encourage employee's commitment and engagement for employee innovative initiatives (Jan \& Hazel, 2013).accountability concern about revealing positive and negative aspect of information (Gergs \& Trinczek, 2008) Who pointed that out "withholding information during phases of radical change is one of the worst mistakes in change management" (p. 152). Hence, based on above discussion, following hypothesis are proposed

H5.1: Participation during the change is significantly and positively influence with employee openness to change

H5.2: Accountability during the change is significantly and positively influence with employee openness to change

H5.3: Substantiality during the change is significantly and positively influence with employee openness to change

Transparent communication and employee organizational trust 
Accountability, substantiality and participatory has pivotal impact on building trust. In the context of public bureaucracies, a sense of efficacy is dependent on one's participatory experiences in the organization. Success in one's attempts to influence changes in the organization increases one's trust in the organization" (Nachmias, 1985, p. 137) . (Auger, 2014) Content the following, Information accessibility helps build trust by reducing uncertainty and perceptions of risk, which in turn facilitates consumer decision-making .Misrepresentation and rumors can create due to the hiding information which leads to misunderstanding and lack of trust and increase insecurity uncertainty and anxiety (Men \& Bowen, 2017)Hence, based on above discussion, following hypothesis are proposed.

H6.1: Participation during the change is significantly and positively influence with employee organizational trust

H6.2: Accountability during the change is significantly and positively influence with employee organizational trust

H6.3: Substantiality during the change is significantly and positively influence with employee organizational trust

\section{Organization trust during change as Mediator}

As mentioned previously, employees make inferences of trust in organizations based on their assessment of their supervisors' or leaders' trustworthiness founded on their interactions with them (Casimir, Waldman, Bartram, \& Yang, 2006; Jung \& Avolio, 2000; Tan \& Tan, 2000). Additionally, trust also results from effective internal communication and in turn affects employee behaviors and overall organizational outcomes (Shockley-Zalabak \& Ellis, 2006).From the internal perspective Employs trust their employer is determined by their cooperation productivity relationship and communication with the organization (Rawlins, 2008). As is evident from the literature discussed above authentic leadership and transparent communication contribute to employees' organizational trust during the change having said so, employees trust the capabilities of leader and organization commitment toward change and believe change will be beneficial and build more behavior toward openness to change. Trust serves as the primary mediator in this process.

Authentic leadership and employee openness.

Self-awareness is explained as the leader's ability to understand his or her strengths weaknesses values and motives, self-awareness is vital in the workplace to understanding the impact your actions have on those you work with or lead is a critical skill in the new workplace. Self-awareness of leader to their strengths and weaknesses can net the trust of others and increase credibility and leads to behavior toward change. An internal moral perspective leader is driven by internal moral value and principle, rather than affected by peer pressure. A leader who is an internalized moral perspective is continuously aiming to achieve consistency in his word and action, which leads subordinates to build trust and supportive behavior toward change. Balance processing refers to taking a stalk holder point of view and input before making a critical decision. Listen and accept the voice of employ leads to build 
trust and openness to change. Leaders build relationship transparency and communication demonstrate true situation to employ and no attempt to hide any information. This leads to building trust with employees and openness to change. Hence, based on the above discussion, the following hypothesis is proposed.

H7.1: organizational trust during a change significantly and positively mediates the effect of Balanced Processing and employee openness to change

H7.2: organizational trust during a change significantly and positively mediates the effect of Internalized Moral Perspective and employee openness to change

H7.3: organizational trust during a change significantly and positively mediates the effect of Relational Transparency and employee openness to change

H7.4: organizational trust during a change significantly and positively mediates the effect of Self-Awareness and employee openness to change

Transparent communication and employee openness to change.

Substantiality refers to provide true and relevant information. The leader that provide true and relevant information increase employ trust and opens to change. Participatory transparency is an organizational effort to involve employees in identifying the most relevant and concerned information to meet their informational needs, Participatory involving employees in the decision-making process and take input. Which increases trust and fostering a culture of change. Accountability dimension which concerns transparency refers to the inclusion of positive and negative information while informing employ which concerns about the revelation of both sides of the story. Employ knowing both the positive and negative side build a strong relationship and desired behavior during the change process. Hence, based on the above discussion, the following hypothesis is proposed.

H8.1: organizational trust during a change significantly and positively mediates the effect of Participation and employee openness to change

H8.2: organizational trust during a change significantly and positively mediates the effect of Accountability and employee openness to change

H8.3: organizational trust during a change significantly and positively mediates the effect of Substantiality and employee openness to change

\section{Transparent communication as a Mediator}

\section{Authentic leadership and organization trust during the change}

Accountability refers to informing negative and positive aspect of information to employ, accountability transparency during the change process help employs to know threat and benefit of change outcome. It's positively mediate between balance processing and organizational trust. The leader who takes input and feedback of employees in decision making and leaders who make transparent the threat and benefit of change outcome, will increase employ trust. Internalized moral perspective leaders take the decision on moral 
standards and achieve consistency with words that can enhance of employ trust can be increased by portraying both sides of information. Relationship transparency has a stronger effect of organizational trust with the mediating role of accountability. because employ who's is aware of true information leads to building trust with the leader. The self-aware leader who know their strengths and weakness and inducing accountability transparency increase involvement and embracing trust.

Participation transparency refers to involving people in decision making and asking to raise voice and input. Participation positively mediates with the balance process because balance process concern about taking feedback of employ and participatory concern about taking input both complement each other and build stronger organizational trust. Internalized moral perceptive leaders have a positive effect on trust with the mediating role of participation. Leaders who take a decision on moral standards and fairness and including accountability transparency listening vice of the subordinate will have a significant impact on trust. Likewise, relationship transparency has a stronger relationship with organizational trust with the mediating role of trust. The self-aware leader has the capability to know their weakness and strength and skill indulging people in decision making and input build stronger coordination among employees and but trust.

Substantiality refers to the identification of most relevant and concerned information to meet employee's informational needs with the involvement of employ. Its positively mediate the balance processing and trust. Because of the balance process concern with taking feedback and input during decision making, while during this process providing substantive information which is relevant information build stronger organization trust to employ. The leader who is internalized moral perspective takes the decision on fairness and moral standard, while in the decision-making process it so identified the most relevant information (substantiality) increase employ organizational trust. Relationship transparency is a strong relationship with trust, while adding concern about true information need to build stronger trust. A self-aware leader has known for their awareness about themselves their strength weakness and action. While incorporating substantiality with action and strength increase e trust.

H9.1: Accountability significantly and positively mediates the effect of Balanced Processing and organization trust during the change.

H9.2: Accountability significantly and positively mediates the effect of Internalized Moral Perspective and organization trust during the change

H9.3: Accountability significantly and positively mediates the effect of Relational Transparency and organization trust during the change

H9.4: Accountability significantly and positively mediates the effect of Self-Awareness and organization trust during the change

H9.5: Participation significantly and positively mediates the effect of Balanced Processing and organization trust during the change 


\section{Macrothink}

H9.6: Participation significantly and positively mediates the effect of Internalized Moral Perspective and organization trust during the change

H9.7: Participation significantly and positively mediates the effect of Relational Transparency and organization trust during the change

H9.8: Participation significantly and positively mediates the effect of Self-Awareness and organization trust during the change

H9.9: Substantiality significantly and positively mediates the effect of Balanced Processing and organization trust during the change

H9.10: Substantiality significantly and positively mediates the effect of Internalized Moral Perspective and organization trust during the change

H9.11: Substantiality significantly and positively mediates the effect of Relational Transparency and organization trust during the change

H9.12: Substantiality significantly and positively mediates the effect of Self-Awareness and organization trust during the change

\section{Model}

In this model: the independent variable is authentic leadership. Transparent communication while the dependent variable was employee openness to change, further this study was comprised of two mediator organization trust during change and transparent communication.

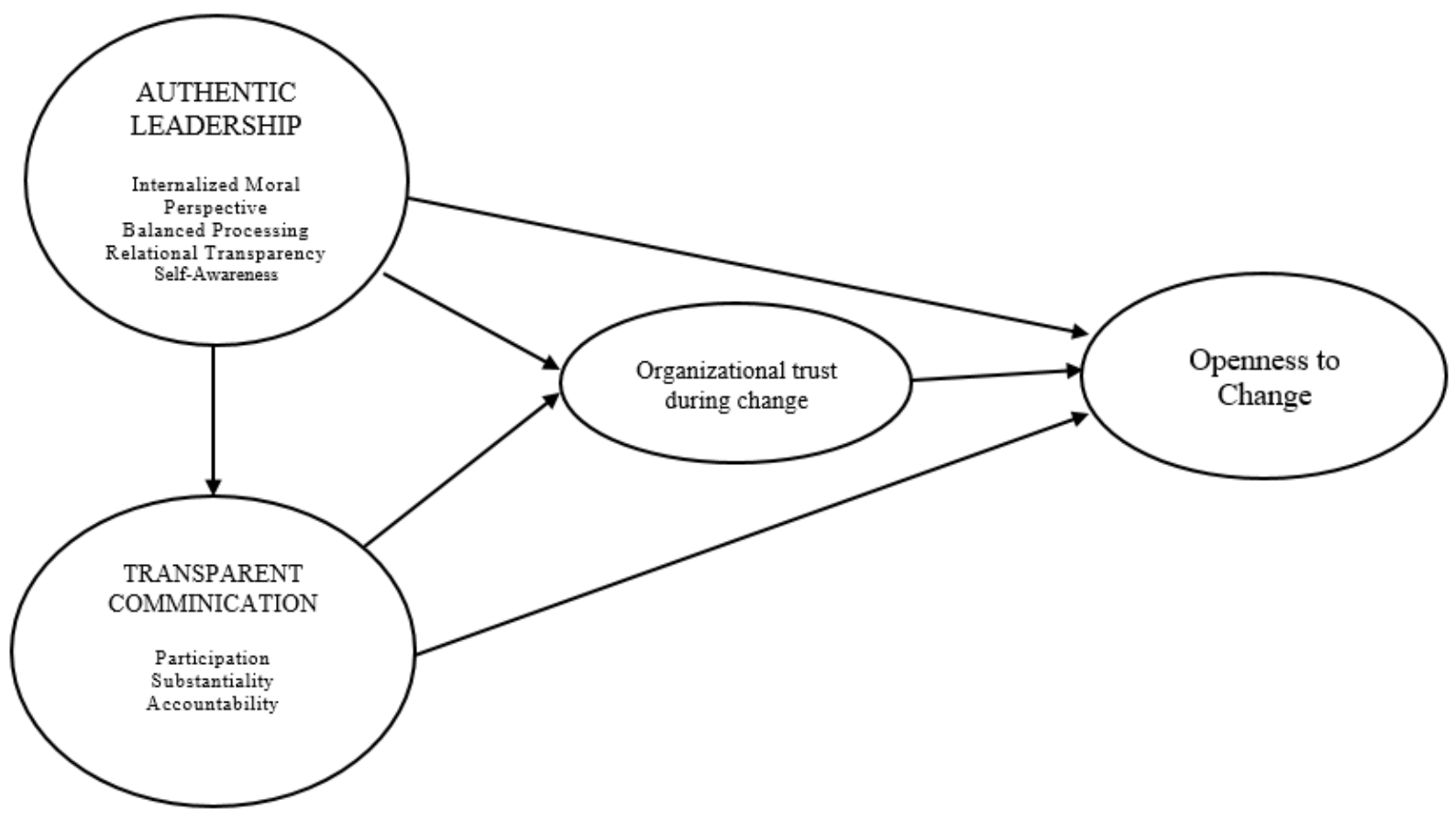

Figure 1. the proposed research framework for this study 


\section{Macrothink}

\section{Research Methodology}

\subsection{Participants}

Total 329 people were contacted to participate in survey that have been circulated around the targeted employs of services industry of Karachi. Focusing on companies who have recently gone through changes in organization Out of 329 survey in which 310 employs responded.

There has been high response because of online survey which include electronic mail, hard copies and shared survey link through mobile.

\subsection{Sampling}

Purposive sampling can be defined as a subtype of non-probability sampling. It can be defined as a sampling which allows researcher to select the participants using their own judgment and decisions (Mackey \& Gass, 2015). Similarly, purposive sampling also deemed as selective and judgmental sampling technique. It can be simply defined as a nonrandom sampling in which the researcher decides what information needs to be known and decide the relevant people that could provide the specific data based on the virtue of knowledge (Tongco, 2007). Therefore, the current study has aimed to use purposive sampling for data collection. The reasons for using purposive sampling were that it allowed the researcher to gather knowledge via certain experts from the specific targeted population or domain. It also helped in directly communicating to the participants and generates required knowledge and results regarding research objective.

\subsection{Demographic Analysis}

Table 1. Frequency distribution of demographic variables

\begin{tabular}{|c|c|c|}
\hline Demographic profile & Frequency & Percentage \\
\hline Gender & & \\
\hline Male & 196 & $67 \%$ \\
\hline Female & 114 & $37 \%$ \\
\hline Age Group & & \\
\hline $21-30$ & 141 & $46 \%$ \\
\hline $31-40$ & 82 & $26 \%$ \\
\hline $41-50$ & 61 & $20 \%$ \\
\hline $51-60$ & 26 & $8 \%$ \\
\hline Education level & & \\
\hline Undergraduate & 68 & $22 \%$ \\
\hline Graduate & 131 & $42 \%$ \\
\hline Post graduate & 111 & $36 \%$ \\
\hline Organization Tenure & & \\
\hline $1-3$ year & 128 & $41 \%$ \\
\hline $4-6$ year & 78 & $25 \%$ \\
\hline $7-9$ year & 62 & $20 \%$ \\
\hline 10 year above & 42 & $14 \%$ \\
\hline Salary & & \\
\hline less than 25000 & 82 & $26 \%$ \\
\hline RS 25000 to 50000 & 126 & $41 \%$ \\
\hline RS 50000 to 75000 & 64 & $21 \%$ \\
\hline more than 75000 & 38 & $12 \%$ \\
\hline
\end{tabular}


As mention above table 1. The final sample included 310 employees in which male responded are more than female. The frequency of Male responded were 196 which are made up of 67percentage of total responded. Female responded compare to male are 114 which is 37percentage of total responded. According the age demographic information state that the youngest age group (21-30) are 141 in frequency which are made up 46 percentages. After that $26 \%$ ( 82 responded) age between (31-40) years. Beside this $20 \%$ (61 responded) fall in range of (41-50) age group and in the end, there are 8\% (26 respondents) of the respondents aged 51 to 60 years old. Based on table the which demonstrate that (22\%) 68 responded are from undergraduate level of education.(42\%) 131 belong to graduate level and lastly (36\%)111 possessed post qualification. According to the table information of organization tenure demonstrate that (41\%) 128 responded fall in category of $1-3$ years. (25\%) 78 of responded have working experience of 4-6 years next to this (20\%) 62 belong to category 7-9 years of organizational experience and lastly (14\%) 42 responded fall between category of 10 years above as organization tenure. Based on above the demographic information regarding salary reveal that (26\%) 82 responded have salary less than 25000 rupees. Followed by that (41\%) 126 have salary range from 25000 to 50000. Next to this $21 \% 64$ responded fall between category of 50001 to 75000 and lastly (12\%) 38 responded have more than 75000 RS.

\subsection{Instruments}

All the vital constructs were measured using items derived from recognized studies that relate and suitable the context of change. The construct comprised of questions measuring the variables Authentic leadership, transparent communication, that constitute two mediating variable organizational trust, and transparent communication and one dependent variable openness to change. All item was recorded on a five-point Likert scale ranging from (1 for strongly disagree) to (5 for strongly agree)

Authentic leadership was measured by a sixteen (16-item) ALQ developed and confirmed by (Walumbwa, Avolio, Gardner, \& Wernsing, 2008) the permission was granted from (www.mindgarden.com) copyright owners. After that it used in this study. study with four conceptual dimensions: (1) self-awareness (2) relational transparency (3) internalized moral perspective and (4) balanced processing (Černe, Jaklič, \& Škerlavaj, 2013; Hsieh \& Wang, 2015; Joo \& Nimon, 2014; Shapira-Lishchinsky \& Tsemach, 2014). Secondly transparent communication was used to measure the level of communication in organization and different aspect of communication. It was assessed by 16 items adapted from (Rawlins, 2009). The transparent communication was measures by three dimensions of transparent communication (Participation, substantiality, accountability) (Men \& Bowen, 2017). Organizational trust during change was used to measure trust between employees and higher hierarchy specially leader, manager and supervisor. It was accessed by Six items adopted from (Rawlins, 2009) and (Hon \& Grunig, 1999) which measure organizational trust or employees trust during process a change. Openness to change was assessed and intend to measure willingness of employees toward change individually or organization necessity toward change, Openness to change was observed using four items adapted from study of (Wanberg \& Banas, 2000). 
Table 2. Descriptive Statistics \& Confirmatory Factor Analysis descriptive result

\begin{tabular}{|c|c|c|c|c|c|c|}
\hline \multirow[b]{2}{*}{ Construct } & \multirow[b]{2}{*}{ Items } & \multicolumn{2}{|r|}{$\begin{array}{c}\text { Descriptive } \\
\text { Statistics }\end{array}$} & \multicolumn{3}{|c|}{$\begin{array}{c}\text { Confirmatory Factor } \\
\text { Analysis }\end{array}$} \\
\hline & & Mean & Standard Deviation & Outer loading & $\begin{array}{c}\mathbf{T} \\
\text { Statistics }\end{array}$ & $\begin{array}{c}\mathbf{P} \\
\text { Values }\end{array}$ \\
\hline \multicolumn{7}{|l|}{ AUTHENTIC LEADERSHIP } \\
\hline \multirow{4}{*}{ Self-Awareness } & SELFAV_1 & 3.448 & 1.271 & 0.793 & 33.091 & 0.000 \\
\hline & SELFAV_2 & 3.513 & 1.182 & 0.874 & 49.249 & 0.000 \\
\hline & SELFAV_3 & 3.365 & 1.155 & 0.883 & 67.003 & 0.000 \\
\hline & SELFAV_4 & 3.374 & 1.131 & 0.837 & 41.071 & 0.000 \\
\hline \multirow{5}{*}{ Relational Transparency } & RELATRANS_1 & 3.477 & 1.262 & 0.799 & 26.250 & 0.000 \\
\hline & RELATRANS_2 & 3.490 & 1.174 & 0.777 & 28.567 & 0.000 \\
\hline & RELATRANS_3 & 3.519 & 1.217 & 0.752 & 23.383 & 0.000 \\
\hline & RELATRANS_4 & 3.684 & 1.135 & 0.837 & 44.680 & 0.000 \\
\hline & RELATRANS_5 & 3.387 & 1.183 & 0.846 & 48.054 & 0.000 \\
\hline \multirow[t]{3}{*}{ Balanced Processing } & BALPRO_1 & 3.513 & 1.129 & 0.793 & 26.143 & 0.000 \\
\hline & BALPRO_2 & 3.552 & 1.219 & 0.886 & 56.096 & 0.000 \\
\hline & BALPRO_3 & 3.490 & 1.109 & 0.878 & 54.416 & 0.000 \\
\hline \multirow[t]{4}{*}{ Internalized Moral Perspective } & IMP_1 & 3.552 & 1.023 & 0.784 & 23.203 & 0.000 \\
\hline & IMP_2 & 3.477 & 1.018 & 0.796 & 28.274 & 0.000 \\
\hline & IMP_3 & 3.506 & 1.201 & 0.750 & 24.807 & 0.000 \\
\hline & IMP_4 & 3.200 & 1.450 & 0.625 & 13.757 & 0.000 \\
\hline \multicolumn{7}{|c|}{ TRANSPARENT COMMUNICATION } \\
\hline \multirow[t]{2}{*}{ Participation } & $\begin{array}{l}\text { The company } \\
\text { asks for } \\
\text { feedback from } \\
\text { people like me } \\
\text { about the quality } \\
\text { of its } \\
\text { information } \\
\text { during the } \\
\text { change. }\end{array}$ & 3.158 & 1.409 & 0.783 & 30.111 & 0.000 \\
\hline & $\begin{array}{l}\text { The company } \\
\text { involves people } \\
\text { like me to help }\end{array}$ & 3.239 & 1.298 & 0.806 & 30.023 & 0.000 \\
\hline
\end{tabular}




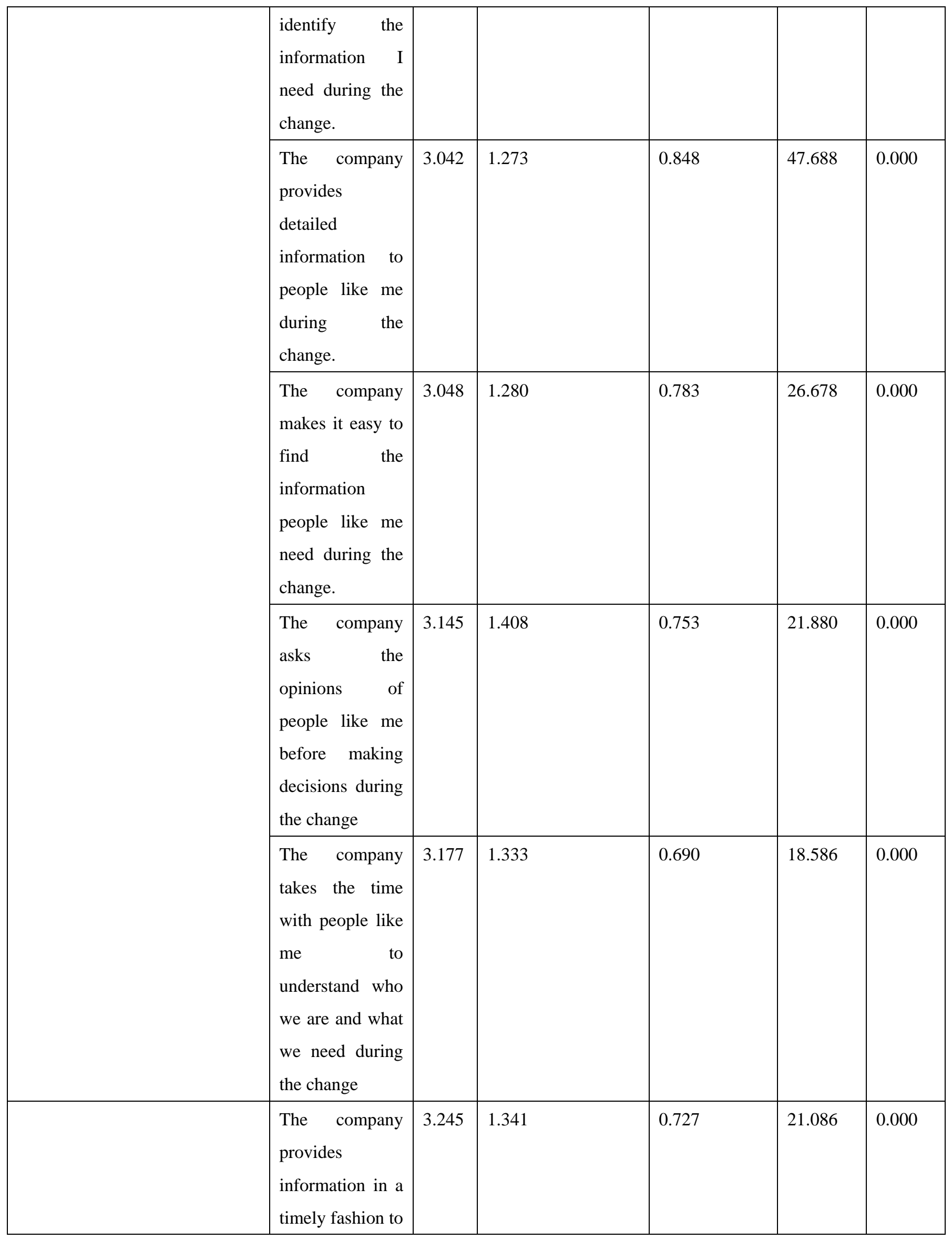




\begin{tabular}{|c|c|c|c|c|c|c|}
\hline \multirow[t]{6}{*}{ Substantiality } & $\begin{array}{l}\text { people like me } \\
\text { during the } \\
\text { change. }\end{array}$ & & & & & \\
\hline & $\begin{array}{l}\text { The company } \\
\text { provides } \\
\text { information that } \\
\text { is relevant to } \\
\text { people like me } \\
\text { during the } \\
\text { change }\end{array}$ & 3.429 & 1.280 & 0.800 & 31.406 & 0.000 \\
\hline & $\begin{array}{l}\text { The company } \\
\text { provides } \\
\text { information that } \\
\text { is complete } \\
\text { during the } \\
\text { change }\end{array}$ & 3.129 & 1.245 & 0.840 & 40.473 & 0.000 \\
\hline & $\begin{array}{l}\text { The company } \\
\text { provides } \\
\text { information that } \\
\text { is easy for } \\
\text { people like me to } \\
\text { understand } \\
\text { during the } \\
\text { change }\end{array}$ & 3.187 & 1.297 & 0.773 & 27.258 & 0.000 \\
\hline & $\begin{array}{l}\text { The company } \\
\text { provides } \\
\text { accurate } \\
\text { information to } \\
\text { people like me } \\
\text { during the } \\
\text { change. }\end{array}$ & 3.245 & 1.353 & 0.801 & 35.683 & 0.000 \\
\hline & $\begin{array}{l}\text { The company } \\
\text { provides } \\
\text { information that } \\
\text { is reliable during } \\
\text { the change. }\end{array}$ & 3.165 & 1.263 & 0.817 & 38.265 & 0.000 \\
\hline & The company & 3.258 & 1.236 & 0.779 & 22.274 & 0.000 \\
\hline
\end{tabular}




\begin{tabular}{|c|c|c|c|c|c|c|}
\hline \multirow[t]{4}{*}{ Accountability } & $\begin{array}{l}\text { presents more } \\
\text { than one side of } \\
\text { controversial } \\
\text { issues during the } \\
\text { change }\end{array}$ & & & & & \\
\hline & $\begin{array}{l}\text { The company is } \\
\text { forthcoming } \\
\text { with information } \\
\text { that might be } \\
\text { damaging to the } \\
\text { organization } \\
\text { during the } \\
\text { change. }\end{array}$ & 3.171 & 1.197 & 0.745 & 21.353 & 0.000 \\
\hline & $\begin{array}{l}\text { The company is } \\
\text { open to criticism } \\
\text { by people like } \\
\text { me during the } \\
\text { change }\end{array}$ & 3.200 & 1.398 & 0.770 & 26.545 & 0.000 \\
\hline & $\begin{array}{l}\text { The company } \\
\text { freely admits } \\
\text { when it has } \\
\text { made mistakes } \\
\text { during the } \\
\text { change. }\end{array}$ & 3.229 & 1.281 & 0.629 & 12.576 & 0.000 \\
\hline \multicolumn{7}{|c|}{ ORGANIZATION TRUST DURING A CHANGE } \\
\hline \multirow[b]{2}{*}{ Organizational Trust } & $\begin{array}{l}\text { I'm willing to let } \\
\text { my organization } \\
\text { make decisions } \\
\text { for people like } \\
\text { me during the } \\
\text { change }\end{array}$ & 3.568 & 1.136 & 0.776 & 29.788 & 0.000 \\
\hline & $\begin{array}{l}\text { I trust my } \\
\text { organization to } \\
\text { take care of } \\
\text { people like me } \\
\text { during the } \\
\text { change. }\end{array}$ & 3.542 & 1.126 & 0.857 & 52.097 & 0.000 \\
\hline
\end{tabular}




\begin{tabular}{|c|c|c|c|c|c|c|}
\hline & $\begin{array}{l}\text { Whenever my } \\
\text { organization } \\
\text { makes an } \\
\text { important } \\
\text { decision during } \\
\text { the change, I } \\
\text { know it will be } \\
\text { concerned about } \\
\text { people like me }\end{array}$ & 3.568 & 1.181 & 0.857 & 45.615 & 0.000 \\
\hline & $\begin{array}{l}\text { My organization } \\
\text { can be relied on } \\
\text { to keep its } \\
\text { promises during } \\
\text { the change }\end{array}$ & 3.542 & 1.103 & 0.865 & 45.876 & 0.000 \\
\hline & $\begin{array}{l}\text { I believe that my } \\
\text { organization } \\
\text { takes the } \\
\text { opinions of } \\
\text { people like me } \\
\text { into account } \\
\text { when making } \\
\text { change-related } \\
\text { decisions }\end{array}$ & 3.413 & 1.146 & 0.781 & 32.630 & 0.000 \\
\hline & $\begin{array}{l}\text { My organization } \\
\text { has the ability to } \\
\text { accomplish what } \\
\text { it says it will do } \\
\text { during the } \\
\text { change. }\end{array}$ & 3.387 & 1.121 & 0.693 & 16.308 & 0.000 \\
\hline \multicolumn{7}{|c|}{ OPENNESS TO CHANGE } \\
\hline \multirow[t]{2}{*}{ Openness to Change } & $\begin{array}{l}\text { I would consider } \\
\text { myself open to } \\
\text { the changes. }\end{array}$ & 3.987 & 1.086 & 0.684 & 15.673 & 0.000 \\
\hline & $\begin{array}{l}\text { I am looking } \\
\text { forward to the } \\
\text { changes in my } \\
\text { work role }\end{array}$ & 3.858 & 1.053 & 0.824 & 29.330 & 0.000 \\
\hline
\end{tabular}




\begin{tabular}{|l|l|l|l|l|l|l|}
\hline & $\begin{array}{l}\text { Overall, the } \\
\text { proposed } \\
\text { changes are for } \\
\text { the better. }\end{array}$ & 1.098 & 0.818 & 29.499 & 0.000 \\
\hline & $\begin{array}{l}\text { I think that the } \\
\text { changes will } \\
\text { have a positive } \\
\text { effect on how I } \\
\text { accomplish my } \\
\text { work }\end{array}$
\end{tabular}

In the above table 2. Authentic leadership questionnaire is not included. Theses questionnaire is copyright $\odot$ of (www.mindgarden.com). All rights reserved to this website.

\subsection{Procedure}

Data was collected from multiple method online survey which include electronic mail and survey link through mobile. The hard copies of questionnaire were distributed in workplace. The purpose of search was explained and ensured that every responded should understand each item in questionnaire. The aim of collecting data was effectively conveyed that how this study will help future leader during change in organization. A portion of survey had demographic information of participant which comprise of Age, Gender, Educational level. Organizational tenure, monthly salary. Questions are designed in a way that holds the responded consideration. Data collected in hard form were 128 and online 182.

\subsection{Data Analysis}

\subsubsection{Structural Equation Modeling}

In this study to test the hypothesize model structural equation modeling SEM was used and research data and interpretation are carried out by Smart PLS (SPLS) software which help to create latent path model in order to test our path model. Numerous analysis can be done by SEM. The data collected would determine the relationship between authentic leadership transparent communication and openness to trust. The Partial Least Squares Structural Equation Modelling (PLS-SEM) requires several critical choices which can lead to improper findings, interpretations, and conclusions if not made correctly and this study is important for researchers and practitioners (Becker, Klein, \& Wetzels, 2012). The (SEM) has been used various regression model and method and it has been perceived leading procedure (Baron \& Kenny, 1987). SEM technique is the combination of factor analysis that also include multiple analysis, it has been used to analyze and examine the structural relationship between measured variables and latent constructs. Likewise, the idea of using this model ensures to apply technique of bootstrapping which has been viewed as reasonable for both small and large sample size and does not require any kind of indirect effect (Hayes, 2013). Bootstrapping technique has been implemented to study the all direct and indirect effects (Shrout \& Bolger, 2002). 


\subsubsection{Measurement of Outer Model}

The aim of measurement of outer model is to seek about model fit. It calculates composite reliability and convergent validity internal consistency of each construct. Internal consistency is measured by composite reliability, In hypothesized model in order to examine reliability and validity we analyzed discrimination validity and convergent validity in Smart partial least squares (SPLS).

\subsubsection{Composite Reliability}

Reliability measure the consistency of items in questionnaire and likewise to check the inter correlation value between the items of a construct. In a construct, all item should echo same measure in a questionnaire. Participant response should be co related with each other.

Composite reliability is a degree of the general reliability of heterogeneous group but similar items (Hair, Hult, Ringle, \& Sarstedt, 2013).Internal consistency reliability is the measure of a value that demonstrate the degree of the latent construct indicated by the construct indicators. Composite reliability is acceptable that exceed value seven (.700). Even though reliability is can be determined by Cronbach Alpha which is extremely popular, the level of CR could determine convergent validity (In \& J, 1993).

Table 3. Composite Reliability

\begin{tabular}{|l|c|}
\hline Variable & $\begin{array}{c}\text { Composite } \\
\text { Reliability }\end{array}$ \\
\hline Accountability & 0.822 \\
\hline Balanced Processing & 0.889 \\
\hline Internalized Moral Perspective & 0.821 \\
\hline Openness to Change & 0.860 \\
\hline Participation & 0.896 \\
\hline Relational Transparency & 0.901 \\
\hline Self-Awareness & 0.911 \\
\hline Substantiality & 0.911 \\
\hline organizational trust during change & 0.918 \\
\hline
\end{tabular}

According to table (3) authentic leader is measured by variable Self-Awareness Relational Transparency Balanced Processing and Internalized Moral Perspective.in which the highest composite reliability was Self-Awareness (0.911). Second highest was Relational Transparent with value of (0.901) and next to this was Balanced Processing with value of (0.889).The lowest was Internalized Moral Perspective (0.821).

Transparent communication measured variable Participation, Substantiality, and Accountability. In which the highest composite reliability was Substantiality (0.911).Second highest was Participation with value (0.896) .The lowest was with the value of Accountability (0.822). Organizational trust with the value of Organizational trust during change (0.918) and 
lastly Openness to Change with value (0.860).

All constructs used in this study have high internal consistency were reliable and value all composite reliability was above (0.700). All constructs used in this study have high internal consistency were reliable and value all composite reliability was above (0.700).

\subsubsection{Factor Loadings Significant}

The factor loadings that demonstrated in table (1). Factor loading must be above 0.500 is considered good and acceptable loading for an indicator (Hair, J F; Black, W C; Balin, B J; Anderson, R E, 2010). According to with table, the measure BALPRO_2 was the highest loading (0.886) and the lowest loading was from the measure IMP_4 (0.625). Three item were deleted for low factor loading, IMP_4 (0.625), I would consider myself open to the changes.(0.684). The company takes the time with people like me to understand who we are and what we need during the change (0.690).

\subsubsection{Convergent Validity}

Convergent validity is the degree to which multiple items to measure the same concept in agreement by item-to-total correlation (Hair, J F; Black, W C; Balin, B J; Anderson, R E, 2010),Conferring to (Claes, David, \& Larcker, 1981)if, the value of AVE is greater than five(0.5) then convergent validity is established and the study is less effective when result is drawn that the loadings are good but less than five(0.5). Average Variance Extracted (AVE) is acceptable when it has value above 0.500 . Convergent validity can be counter checked by average variance extracted (AVE) Value .following table 4 displays the result.

Table 4. Convergent Validity

\begin{tabular}{|l|l|l|l|l|}
\hline Variable & $\begin{array}{l}\text { Cronbach's } \\
\text { Alpha }\end{array}$ & rho_A & $\begin{array}{l}\text { Composite } \\
\text { Reliability }\end{array}$ & $\begin{array}{l}\text { Average } \\
\text { Variance } \\
\text { Extracted } \\
\text { (AVE) }\end{array}$ \\
\hline Accountability & 0.711 & 0.718 & 0.822 & 0.538 \\
\hline Balanced Processing & 0.812 & 0.815 & 0.889 & 0.728 \\
\hline Internalized Moral Perspective & 0.672 & 0.674 & 0.821 & 0.604 \\
\hline Openness to Change & 0.756 & 0.756 & 0.860 & 0.672 \\
\hline Participation & 0.854 & 0.857 & 0.896 & 0.632 \\
\hline Relational Transparency & 0.862 & 0.866 & 0.901 & 0.645 \\
\hline Self-Awareness & 0.869 & 0.871 & 0.911 & 0.718 \\
\hline Substantiality & 0.882 & 0.885 & 0.911 & 0.630 \\
\hline organizational trust during change & 0.891 & 0.894 & 0.918 & 0.652 \\
\hline
\end{tabular}

Above table demonstrate that all the constructs have AVE above (0.500). The situation shows that the general amount of variance had surpassed the recommended value wherein the 


\section{MInstitute ${ }_{\text {Mnk }}^{\text {Macrothink }}$}

indicators accounted for by the latent construct.

\subsubsection{Discriminant Validity}

Discrimination validity help us to understand within in same model that two measure are not co related or actually related. Furthermore that demonstrate that any construct when differ from other construct in same model. Discriminant validity's main objective to ensure that different variables is no significant variance among that could have the same reason. According to (Hair, J F; Black, W C; Balin, B J; Anderson, R E, 2010) .Within the same model the dissimilarity between one construct towards the other is explained. Further that, the square root value of average variance extended (AVE) of each construct must be greater than the correlations with the other constructs in same model. (Claes, David, \& Larcker, 1981) .when the constructs are having an AVE loading more than $(>0.5)$ which means that minimum $50 \%$ of variance was took by the construct in which Discriminate validity results are satisfactory (Chin \& Marcoulides, 1998).

Table 5. Discrimination validity

\begin{tabular}{|l|l|l|l|l|l|l|l|l|l|}
\hline & ACC & BALPRO & IMP & OPCH & PARTI & RELATRANS & SELFAV & SUBS & ORG \\
\hline Accountability & 0.733 & & & & & & & & \\
\hline Balanced Processing & 0.577 & 0.853 & & & & & & & \\
\hline Internalized Moral Perspective & 0.807 & 0.667 & 0.777 & & & & & & \\
\hline Openness to Change & 0.392 & 0.472 & 0.434 & 0.820 & & & & & \\
\hline Participation & 0.714 & 0.678 & 0.629 & 0.478 & 0.795 & & & & \\
\hline Relational Transparency & 0.590 & 0.798 & 0.682 & 0.440 & 0.711 & 0.803 & & & \\
\hline Self-Awareness & 0.619 & 0.814 & 0.735 & 0.483 & 0.826 & 0.823 & 0.847 & & \\
\hline Substantiality & 0.738 & 0.777 & 0.619 & 0.464 & 0.846 & 0.759 & 0.728 & 0.794 & \\
\hline organizational trust during change & 0.570 & 0.774 & 0.604 & 0.589 & 0.667 & 0.832 & 0.752 & 0.685 & 0.807 \\
\hline
\end{tabular}

\subsection{Evaluation of the Inner Structural Model}

The measurement model was analyzed above, the result confirmed its validity and reliability. Now the second step has to examine the inner structural model outcomes. The inner structural model incudes measuring the value of R2. Which explain the goodness of fit model and examine the variance of variable. Next to this we examined the model fit measure which comprised of 5 factor which demonstrate correlation between variable.

\subsubsection{Measuring the Value of R2}

Goodness-of-fit model is measured by R-squared (coefficient) in linear regression models. R2 square statistic show the variance between dependent variable that the independent variable explain collectivity and demonstrated in percentage. The link between dependent variable and hypothesized model showed in range of (0-100) percentage .According to (Henseler, J; Hubona, G; Ray, P A, 2016) and (Hair, J F; Black, W C; Balin, B J; Anderson, R E, 2010). 


\section{Macrothink}

International Journal of Human Resource Studies

The value of R2 $(0.75)$ is considered substantial following that that value of $\mathrm{R} 2(0.50)$ is considered moderate and value of R2 (0.26) considered weak.

Based on the table. The value of R2 of organizational trust during change is (0.740) while Accountability (0.655), Openness to Change (0.407) Participation (0.686) and Substantiality (0.662).

Table 6. Measuring the value of R2

\begin{tabular}{|l|l|l|}
\hline Variables & R Square & $\begin{array}{l}\text { R Square } \\
\text { Adjusted }\end{array}$ \\
\hline Accountability & 0.655 & 0.650 \\
\hline Openness to Change & 0.407 & 0.391 \\
\hline Participation & 0.686 & 0.682 \\
\hline Substantiality & 0.662 & 0.658 \\
\hline organizational trust during change & 0.740 & 0.734 \\
\hline
\end{tabular}

\subsubsection{Model Fit Measures}

Model fit measures in Smart PLs can be demonstrated by various factor. Smart PLs can demonstrated measurement of model fitness by (1) SRMR (2) Chi² (3) RMS_theta (4) Exact fit criteria d_ULS and d_G (5) NFI. Correlation between all constructs can be accessed by the saturated model. According to (Hu \& Bentler, 1998). The value of SRMR less than 0.10 or of 0.08 is believed to be good model fit. The study found the model fit well

Table 7. Model fit

\begin{tabular}{|l|c|c|}
\hline & Saturated Model & Estimated Model \\
\hline SRMR & 0.088 & 0.097 \\
\hline d_ULS & 6.031 & 7.349 \\
\hline d_G & 5.114 & 5.397 \\
\hline Chi-Square & 6896.576 & 7144.122 \\
\hline NFI & 0.499 & 0.481 \\
\hline
\end{tabular}

\subsection{Hypothesis Testing}

The bootstrapping procedure was used to evaluate the significance of the hypothesis. (Chin W. W., 1998). For this study bootstrapping was run in Smart PLs software. The aim is to test the fitness of the model with data. Bootstrapping report showed the $\mathrm{T}$ value and $\mathrm{P}$ values. That illustrate structural model fitness and determine the relationship between the latent variable significant or not. IF the t-value greater than $1.96(\mathrm{p}<.005)$ shows that the relationship is significant at $95 \%$ confidence level $(\alpha=0.05)$. 


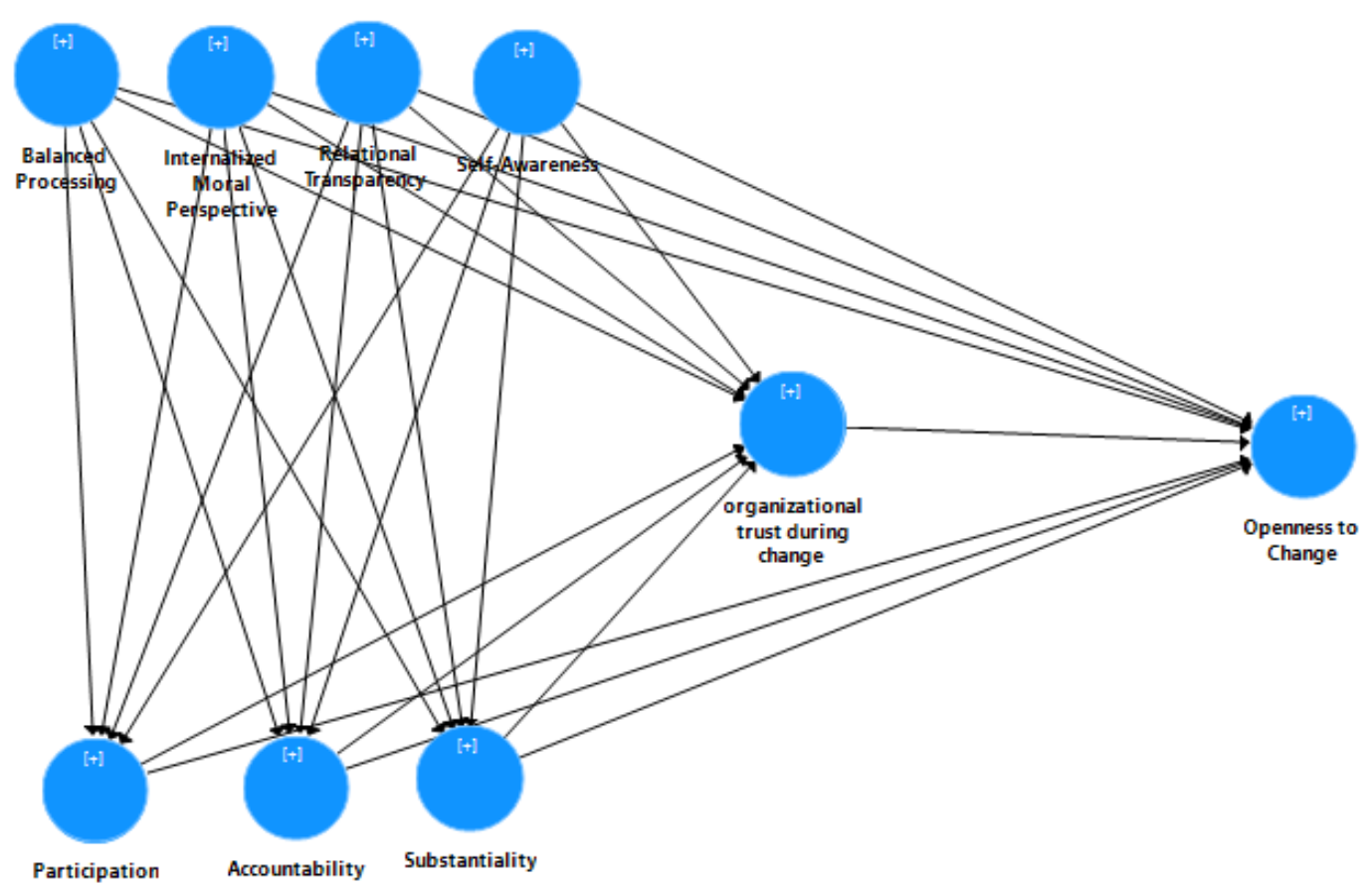

Figure 2. Path Diagram

The below table 8 . Show the result of path coefficient of all hypothesis.

Table 8. Test of Hypothesis

\begin{tabular}{|c|c|c|c|c|}
\hline Hypothesized Path & $\begin{array}{l}\text { Original } \\
\text { Sample }\end{array}$ & T Statistics & $\begin{array}{c}\mathbf{P} \\
\text { Values }\end{array}$ & RESULT \\
\hline \multicolumn{5}{|c|}{ Authentic leadership during the change is significantly and positively influence with employee openness to change. } \\
\hline $\begin{array}{l}\text { H0.1.1: Relational Transparency during the change is significantly and } \\
\text { positively influence with employee openness to change }\end{array}$ & -0.434 & 4.235 & 0.000 & supported \\
\hline $\begin{array}{l}\text { H0.1.2: Internalized Moral Perspective during the change is significantly and } \\
\text { positively influence with employee openness to change }\end{array}$ & 0.305 & 2.482 & 0.007 & supported \\
\hline $\begin{array}{l}\text { H0.1.3: Self-Awareness during the change is significantly and positively } \\
\text { influence with employee openness to change }\end{array}$ & -0.010 & 0.162 & 0.436 & Not supported \\
\hline $\begin{array}{l}\text { H0.1.4: Balanced Processing during the change is significantly and } \\
\text { positively influence with employee openness to change }\end{array}$ & -0.068 & 0.549 & 0.292 & Not supported \\
\hline \multicolumn{5}{|c|}{ Authentic leadership during the change is significantly and positively influence employee organizational trust } \\
\hline $\begin{array}{l}\text { H0.2.1: Balanced Processing during the change is significantly and } \\
\text { positively influence employee organizational trust }\end{array}$ & 0.355 & 5.168 & 0.000 & supported \\
\hline $\begin{array}{l}\text { H0.2.2: Internalized Moral Perspective during the change is significantly and } \\
\text { positively influence employee organizational trust }\end{array}$ & -0.162 & 2.498 & 0.006 & supported \\
\hline H0.2.3: Relational Transparency during the change is significantly and & 0.593 & 10.501 & 0.000 & Supported \\
\hline
\end{tabular}




\begin{tabular}{|c|c|c|c|c|}
\hline \multicolumn{5}{|l|}{ positively influence employee organizational trust } \\
\hline $\begin{array}{l}\text { H0.2.4: Self-Awareness during the change is significantly and positively } \\
\text { influence employee organizational trust }\end{array}$ & 0.025 & 0.264 & 0.396 & Not supported \\
\hline \multicolumn{5}{|c|}{ Authentic leadership during the change is significantly and positively influence transparent communication } \\
\hline $\begin{array}{l}\text { H0.3.1: Balanced Processing during the change is significantly and } \\
\text { positively influence Accountability }\end{array}$ & 0.047 & 0.818 & 0.207 & Not supported \\
\hline $\begin{array}{l}\text { H0.3.2: Balanced Processing during the change is significantly and } \\
\text { positively influence Participation }\end{array}$ & -0.026 & 0.481 & 0.315 & Not supported \\
\hline $\begin{array}{l}\text { H0.3.3: Balanced Processing during the change is significantly and } \\
\text { positively influence Substantiality }\end{array}$ & 0.413 & 7.358 & 0.000 & Supported \\
\hline $\begin{array}{l}\text { H0.3.4: Internalized Moral Perspective during the change is significantly and } \\
\text { positively influence Participation }\end{array}$ & 0.035 & 0.649 & 0.258 & Not supported \\
\hline $\begin{array}{l}\text { H0.3.5: Internalized Moral Perspective during the change is significantly and } \\
\text { positively influence Accountability }\end{array}$ & 0.732 & 16.092 & 0.000 & Supported \\
\hline $\begin{array}{l}\text { H0.3.6: Internalized Moral Perspective during the change is significantly and } \\
\text { positively influence Substantiality }\end{array}$ & 0.070 & 1.428 & 0.077 & Not supported \\
\hline $\begin{array}{l}\text { H0.3.7: Relational Transparency during the change is significantly and } \\
\text { positively influence Participation }\end{array}$ & 0.101 & 1.717 & 0.043 & Supported \\
\hline $\begin{array}{l}\text { H0.3.8: Relational Transparency during the change is significantly and } \\
\text { positively influence-Accountability }\end{array}$ & 0.067 & 1.119 & 0.132 & Not supported \\
\hline $\begin{array}{l}\text { H0.3.9: Relational Transparency during the change is significantly and } \\
\text { positively influence Substantiality }\end{array}$ & 0.313 & 6.104 & 0.000 & Supported \\
\hline $\begin{array}{l}\text { H0.3.10: Self-Awareness during the change is significantly and positively } \\
\text { influence Participation }\end{array}$ & 0.739 & 10.923 & 0.000 & Supported \\
\hline $\begin{array}{l}\text { H0.3.11: Self-Awareness during the change is significantly and positively } \\
\text { influence Accountability }\end{array}$ & -0.010 & 0.162 & 0.436 & Not supported \\
\hline $\begin{array}{l}\text { H0.3.12: Self-Awareness during the change is significantly and positively } \\
\text { influence Substantiality }\end{array}$ & 0.083 & 1.266 & 0.103 & Not supported \\
\hline $\begin{array}{l}\text { H0.0.4.1: Employee organizational trust during the change is significantly } \\
\text { and positively influence with employee openness to change. }\end{array}$ & 0.700 & 6.556 & 0.000 & Supported \\
\hline \multicolumn{5}{|c|}{ transparent communication during the change is significantly and positively influence with employee openness to change } \\
\hline $\begin{array}{l}\text { H0.5.1: Participation during the change is significantly and positively } \\
\text { influence with employee openness to change }\end{array}$ & 0.153 & 1.386 & 0.083 & Not supported \\
\hline $\begin{array}{l}\text { H0.5.2: Accountability during the change is significantly and positively } \\
\text { influence with employee openness to change }\end{array}$ & -0.232 & 2.388 & 0.008 & Supported \\
\hline H0.5.3: Substantiality during the change is significantly and positively & 0.218 & 1.795 & 0.036 & Supported \\
\hline
\end{tabular}


influence with employee openness to change

transparent communication during the change is significantly and positively influence with employee organizational trust

\begin{tabular}{|l|l|l|l|l|}
\hline $\begin{array}{l}\text { H0.6.1: Participation during the change is significantly and positively } \\
\text { influence with employee organizational trust }\end{array}$ & 0.120 & 1.374 & 0.085 & Not supported \\
\hline $\begin{array}{l}\text { H0.6.2: Accountability during the change is significantly and positively } \\
\text { influence with employee organizational trust }\end{array}$ & 0.204 & 3.414 & 0.000 & Supported \\
\hline $\begin{array}{l}\text { H0.6.3: Substantiality during the change is significantly and positively } \\
\text { influence with employee organizational trust }\end{array}$ & -0.210 & 2.590 & 0.005 & Supported \\
\hline
\end{tabular}

Above Table (8) shows the direct relationships of the independent variables to the mediating variable, the direct relationship of the mediating variable to the dependent variable

According with above table the study examined, two out of four direct relationship of authentic leader show significance and positively influence employees openness to change has been supported, hence hypothesis (H0.1.1\& H0.1.2) indicated Relationship Transparency $(\mathrm{T}=4.235, \mathrm{p}<0.000)$ and internal moral perspective $(\mathrm{T}=2.482, \mathrm{p}<0.007)$ has showed significant relationship to employees openness to change,.

So in Pakistan specifically in services industry there is significant effect Transparency and internal moral perspective to build employees openness to change during change process

Beside this, authentic leadership during the change is significantly and positively influence employee organizational trust. Has been supported. It's indicated three out four show significance relationship with trust namely that Balanced Processing $((\mathrm{T}=5.168, \mathrm{p}<0.000)$, Internalized Moral Perspective $(\mathrm{T}=2.498, \mathrm{p}<0.006)$, :Relational Transparency $(\mathrm{T}=10.501, \mathrm{p}$ $<0.000$. Supporting the hypothesis (H0.2.1, H0.2.2, and H0.2.3).

This study revealed in service industry of Pakistan, there is statistically significant evidence that employees trust during the change process can be influence by Balanced Processing, Internalized Moral Perspective, and Relational Transparency

As shown in table (8) as we predicted authentic leadership during the change is significantly and positively influence transparent communication, has not been supported. It demonstrates that 7 hypothesis showed no significant relationship between authentic leadership and transparent communication (H0.3.1, H0.3.2, H0.3.4, H0.3.6, H0.3.8, H0.3.11, H3.12). While only 5 hypothesis (H0.3.3, H03.5, H0.3.7, H0.3.9, and $\mathrm{H} 0.3 .10)$ showed significant relationship between authentic leadership and transparent communication. Hence in Pakistan, Balanced Processing during the change is significantly and positively influence Substantiality, Internalized Moral Perspective during the change is significantly and positively influence Accountability, Relational Transparency during the change is significantly and positively influence Participation, Relational Transparency during the change is significantly and positively influence Substantiality, Self-Awareness during the change is significantly and positively influence Participation

As shown above table (8) as we predicted that Employee organizational trust during the 


\section{Macrothink Institute ${ }^{\mathrm{TM}}$}

International Journal of Human Resource Studies ISSN 2162-3058 2020, Vol. 10, No. 3

change is significantly and positively influence with employee openness to change. Has been supported $(\mathrm{T}=6.556, \mathrm{p}<0.000)$. Thus accepting (H0.0.4.1.). Empirical study proves in Pakistan trust play a essential during change process

According to table (8), as we predicted transparent communication during the change is significantly and positively influence with employee openness to change. Has been supported. In which two of three show significant relationship with openness to change namely Accountability $(\mathrm{T}=2.388, \mathrm{p}<0.008)$ and Substantiality $(\mathrm{T}=1.795 \mathrm{p}<0.036)$ Thus accepting (H0.5.2, H0.5.3).

According to table (8) as we predicted that there is significant relationship between transparent communication employee organizational trust during change process. Has been supported. In which two out three showing positive relationship with organizational trust namely (Accountability $\mathrm{T}=3.414, \mathrm{p}<0.000)$, Substantiality $(\mathrm{T}=2.590, \mathrm{p}<0.005$ thus accepting (H0.6.2, H0.6.3).

Table 9. Indirect Test of Hypothesis

\begin{tabular}{|c|c|c|c|c|}
\hline Hypothesized Path & $\begin{array}{l}\text { Original } \\
\text { Sample }\end{array}$ & T & $\begin{array}{l}\mathbf{P} \\
\text { Values }\end{array}$ & RESULT \\
\hline \multicolumn{5}{|c|}{$\begin{array}{l}\text { Organizational trust during a change significantly and positively mediates the effect of authentic leadership and employee openness to } \\
\text { change }\end{array}$} \\
\hline $\begin{array}{l}\text { H0.7.1: Balanced Processing }->\text { organizational trust during change -> Openness } \\
\text { to Change }\end{array}$ & 0.248 & 3.921 & 0.000 & supported \\
\hline $\begin{array}{l}\text { H 0.7.2: Internalized Moral Perspective }->\text { organizational trust during change }-> \\
\text { Openness to Change }\end{array}$ & -0.114 & 2.248 & 0.012 & supported \\
\hline $\begin{array}{l}\text { H0.7.3: Relational Transparency } \rightarrow \text { organizational trust during change }-> \\
\text { Openness to Change }\end{array}$ & 0.415 & 6.052 & 0.000 & supported \\
\hline $\begin{array}{l}\text { H0.7.4 Self-Awareness -> organizational trust during change }->\text { Openness to } \\
\text { Change }\end{array}$ & 0.017 & 0.257 & 0.398 & Not supported \\
\hline \multicolumn{5}{|c|}{$\begin{array}{l}\text { Organizational trust during a change significantly and positively mediates the effect of transparent communication and employee openness to } \\
\text { change. }\end{array}$} \\
\hline $\begin{array}{l}\text { H0.8.1: Participation } \rightarrow \text { organizational trust during change } \rightarrow \text { Openness to } \\
\text { Change }\end{array}$ & 0.084 & 1.333 & 0.091 & Not supported \\
\hline $\begin{array}{l}\text { H0.8.2: Accountability -> organizational trust during change }->\text { Openness to } \\
\text { Change }\end{array}$ & 0.143 & 2.984 & 0.001 & supported \\
\hline $\begin{array}{l}\text { H0.8.3: Substantiality } \rightarrow \text { organizational trust during change } \rightarrow \text { Openness to } \\
\text { Change }\end{array}$ & -0.147 & 2.454 & 0.007 & supported \\
\hline \multicolumn{5}{|c|}{$\begin{array}{l}\text { Transparent communication during the significantly and positively mediates the effect of authentic leadership and organization trust during } \\
\text { the change }\end{array}$} \\
\hline H0.9.1: Balanced Processing $\rightarrow$ Accountability $\rightarrow$ organizational trust during & 0.010 & 0.740 & 0.230 & Not supported \\
\hline
\end{tabular}




\section{Macrothink}

International Journal of Human Resource Studies

ISSN 2162-3058

2020, Vol. 10, No. 3

\begin{tabular}{|c|c|c|c|c|}
\hline change & & & & \\
\hline $\begin{array}{l}\text { H0.9.2: Internalized Moral Perspective }->\text { Accountability }->\text { organizational trust } \\
\text { during change }\end{array}$ & 0.149 & 3.180 & 0.001 & supported \\
\hline $\begin{array}{l}\text { H0.9.3:Relational Transparency -> Accountability -> organizational trust during } \\
\text { change }\end{array}$ & 0.014 & 1.072 & 0.142 & Not supported \\
\hline H0.9.4: Self-Awareness -> Accountability -> organizational trust during change & -0.002 & 0.156 & 0.438 & Not supported \\
\hline $\begin{array}{l}\text { H0.9.5: Balanced Processing } \rightarrow \text { Participation }->\text { organizational trust during } \\
\text { change }\end{array}$ & -0.003 & 0.389 & 0.349 & Not supported \\
\hline $\begin{array}{l}\text { H 0.9.6: Internalized Moral Perspective }->\text { Participation }->\text { organizational trust } \\
\text { during change }\end{array}$ & 0.004 & 0.494 & 0.311 & Not supported \\
\hline $\begin{array}{l}\text { H0.9.7 Relational Transparency -> Participation -> organizational trust during } \\
\text { change }\end{array}$ & 0.012 & 0.974 & 0.165 & Not supported \\
\hline H0.9.8: Self-Awareness -> Participation -> organizational trust during change & 0.089 & 1.369 & 0.086 & Not supported \\
\hline $\begin{array}{l}\text { H0.9.9: Balanced Processing } \rightarrow \text { Substantiality } \rightarrow \text { organizational trust during } \\
\text { change }\end{array}$ & -0.087 & 2.344 & 0.010 & supported \\
\hline $\begin{array}{l}\text { H0.9.10: Internalized Moral Perspective }->\text { Substantiality }->\text { organizational trust } \\
\text { during change }\end{array}$ & -0.015 & 1.226 & 0.110 & Not supported \\
\hline $\begin{array}{l}\text { H0.9.11: Relational Transparency }->\text { Substantiality }->\text { organizational trust during } \\
\text { change }\end{array}$ & -0.066 & 2.399 & 0.008 & supported \\
\hline H0.9.12: Self-Awareness -> Substantiality $->$ organizational trust during change & -0.017 & 1.073 & 0.142 & Not supported \\
\hline
\end{tabular}

As table show specific indirect effect of variable, which demonstrate that there is significant relationship between authentic leader and employees openness to change by mediating role of organizational trust .furthermore, transparent communication is significant relationship with employee openness to change by mediating role of organizational trust meanwhile it shows weak relationship between authentic leadership and organizational trust by mediating role of transparent communication

According to above table (9) that show, as we predicted organizational trust during a change positively mediates the effect of authentic leadership and employee openness to change. Has been supported. Organization trust found to be a significant mediator between Balanced Processing and openness to change $(\mathrm{T}=3.921, \mathrm{p}<0.000)$, Internalized Moral Perspective and openness to change $(\mathrm{T} 2.248=, \mathrm{p}<0.012)$, Relational Transparency and openness to change $(\mathrm{T}=6.052=, \mathrm{p}<0.000)$.thus accepting (H0.7.1, H0.7.2, H0.7.3) while Self-Awareness $(\mathrm{T}=0.257=, \mathrm{p}<0.398)$ show weak relationship. So rejecting hypothesis $(\mathrm{H} 0.7 .4)$

As shown in above table (9), Which indicate that Participation ( $\mathrm{T}=0.770, \mathrm{p}<0.221)$ is weak relationship with employees openness to change, so rejecting hypothesis (H0.8.1).furthermore there is significance relationship between transparent communication and openness to change via mediating role of trust during change has been supported. Which indicated organization trust found to be a significant mediator between accountability and 
openness to change $(\mathrm{T}=2.984, \mathrm{p}<0.001)$, substantiality and openness to change $(\mathrm{T}=2.454, \mathrm{p}$ $<0.007)$. Thus accepting (H0.8.2, H0.8.3)

As shown table (9) as we predicted transparent communication during the change is significantly and positively mediates the effect of authentic leadership and organization trust during the change has not been supported. Which indicate that (H0.9.1, H0.9.3 H0.9.4, H0.9.5.H 0.9.6, H0.9.7, H0.9.8, H0.9.10, H0.9.12) shows weak relationship.

However, transparent communication found to be a significant mediator between the following: Accountability ( $\mathrm{T}=3.180, \mathrm{p}<0.001)$ during the change significantly and positively mediates the effect of Internalized Moral Perspective and organization trust, Substantiality ( $\mathrm{T}=2.454, \mathrm{p}<0.007)$ during the change significantly and positively mediates the effect of Balanced Processing and organization trust during the change.(H0.9.11) Substantiality $(\mathrm{T}=2.399, \mathrm{p}<0.010)$ during the change significantly and positively mediates the effect of Relational Transparency and organization trust. Thus accepting $(\mathrm{H} 0.9 .2)(\mathrm{H} 0.9 .9)(\mathrm{H} 0.9 .11)$.

\section{Discussions}

This study found that authentic leadership has a significant impact on employ openness to change. Going further research identified that Relationship transparency has a significant impact on employ openness to change. Thus providing empirical support for (H0.1.1). This demonstrates relationship transparency is associated with building supportive and transparent behavior toward employ and giving access to ideas and information, solicit ideas from subordinate.which leads to fostering a culture of employ openness to change. Relational transparency mainly deals with the sharing information openly and realizing and building openness to others by sharing their true ideas (Avolio, Walumbwa, \& Weber, 2009). Furthermore study predicted that Self-Awareness shows an insignificant relationship to openness to change. Employs who are facing change in organization less likely to be impacted by the self-awareness of leadership. Leaders who know themselves well and aware of their cognition, strength, and emotion don't impact on employ openness to change and this is surprising as existing theoretical framework suggests that there positive relationship between self-awareness and employ openness to change. Self-awareness is knowing your emotion value, cognition knowing is weakness and strength has effective building behavior of openness to change. (Avolio \& Gardner, 2005). This study also uncovered that Balanced Processing (H0.1.4) shows insignificant relationship in building employ openness to change. The reason behind is this, in services of industry Pakistan employs feels they are not given the platform to share voices, concern, point of view, and knowledge in deciding on about the change, contradicted study (Gardner, Avolio, Luthans, \& May, 2005) that state balance process shows that taking each stakeholder point of view making decision. And pre and well planned action is significant role openness to change.

The finding suggest that there is significant relationship between authentic leadership and trust. Authentic leader who are authentic and build strong relation transparency with employ, impact the employ trust during the change. Authentic leadership and employees trust are positively associated that is identified by multiple researchers (Casimir, Waldman, Bartram, \& Yang, 2006; Dietz, 2011; Jung \& Avolio, 2000; Kouzes \& Posner, 2002; Tan \& Tan, 2000). 
The study finding lead the researcher to reject the (H0.2.4) Self-Awareness is insignificant relationship with building organizational trust during change. That shows that self-awareness is no positive effect on organizational trust, The reason behind this employs feels that self-awareness of leadership knowing their strength and weakness may work against them and form dictatorship, which can lead to neutralizing the employs strength and voice o during the change. The finding indicated that there is no significant relationship between authentic leadership and transparent communication during the change process, has not been supported by empirical study. The reason behind is that employ feels that during the change leaders don't share accurate and relevant information to employs such as job security, layoff, demotion which leads to uncertainty about future and less focusing on the change process, Its contradicted the previous literature that state that authentic managers significantly contribute to the cultivation and enhancement of transparent organizational communication, which further promotes a nurturing organizational environment where employees demonstrate a high level of positive affect toward their employers and feel empowered to actively participate in organizational life. (Menguc, Auh, Fisher, \& Haddad, 2013; Saks, A M;, 2006).

The result demonstrate that organizational trust have significant relation with openness to change. Empirical study show significant relationship thus supporting (H0.4.1). This stresses out more employees trust their organizations during the change. They are dependent on organizational word, action, and intention in the process of change and they are more likely to develop behavior and attitude toward change. Thus this is consistent with study (Fugate, Prussia, \& Kinicki, 2012), that state their attitudes and behaviors during the change significantly impact the change outcome (Fugate, Prussia, \& Kinicki, 2012). Additionally, trust also results from effective internal communication and in turn affects employee behaviors and overall organizational outcomes (Shockley-Zalabak \& Ellis, 2006).

The study exerts that transparent communication is a strong and significant direct relationship with employees' openness to change. Organizational communication which is ethical open and honest can eradiate the gap between employees and their leaders in the organization. Transparent communication paves the way toward change by reducing misinformation and anxiety and leads to perceived organizational behavior. This study provide empirical evidence and It consistent with study (Avolio, Gardner, Walumbwa, Luthans, \& May, 2004) which state that the leaders who make their values transparent to employs and concern about subordinate interest and have moral standard, can nurture pro organizational environment. This study has shown that there is strong direct relationship between transparent communication and trust. it is consistent to prior research, according to (Jiang \& Luo, 2018; Rawlins, 2008) which state that scholars of Public relations have consistently found that transparent communication provide various positive employee outcomes, such as employee trust contribution. Furthermore, the study shows that Accountability is a significant relationship with trust. Employs during the change feel that, if the organization is clear about is the decision about change and they ensure portraying the positive and negative impact of the change process to employ. Employs feel less anxiety and less uncertainty about the future and build trust in organization intention and implementation. In addition, substantiality shows a significant relationship to trust. The reason behind is that employees feel leader providing 
truthful, concern, providing key and relevant information during the change process, which leads to building coordination, cooperation, and building trust

The finding of the result suggests that there is a strong and indirect relationship between authentic leadership and employees' openness to change in the mediating role of trust. The reason behind this is that an authentic leader is morally grounded and possess ethical behavior which in turn build the transparent relationship, they actively take input of employ such as ideas and decision making are the major factor building confidence and trust. Which nurture behavior toward change. Study is consistent with study (Shockley-Zalabak \& Ellis, 2006) which state that employees desired behavior and productivity are linked by trust which result in higher productivity, higher committed employees and high job satisfaction. However self-awareness showed insignificance relationship with openness to change with mediating role of trust. Employ feels that leader who is self-aware about themselves doesn't impact the openness to change, the reason behind is that self-aware leaders are mostly too focused on themselves, become sensitive and curious about the change outcome which leads ignoring the concern about employees and uncertainly about future. Furthermore, Study proved that there is strong indirect relationship between transparent communications and openness to change. The reason behind is that during the change transparent communication eradicate uncertainty, misinformation, increase coordination and collaboration among the employs, employ trust more organization when are fully aware of the future and exert behavior toward openness to change, its consistent with previous literature finding. Transparent communication paves the way toward employees trust and credibility of organization and its gain attention by scholar and professional (Rawlins, 2008; Rawlins, 2009). Whereas, this study reveal that there is weak relationship between authentic leaders and organizational trust by mediating role of transparent communication. It demonstrates employs less likely to build trust with authentic leader with mediating role of trust. This is surprising as previous theoretical framework suggest that state Authentic leadership and employees trust are positively associated that is identified by multiple researchers (Casimir, Waldman, Bartram, \& Yang, 2006; Dietz, 2011; Jung \& Avolio, 2000; Kouzes \& Posner, 2002; Tan \& Tan, 2000). Yet, its indirect effect upon via transformation communication is mediator showed weak relationship. However, substantiality also offered a partial mediatory role between authentic leadership and trust. The reason behind is that. If the leader builds open contact with subordinates through the exchange of honest, substantive, meaningful information, leads to builds teamwork and collaboration. That contributes to trust in organizational decisions and change implication.

\section{Conclusion}

The focus of this research is to examine the relationship between authentic leadership, transparent communication, employee's openness to change and mediating role trust and transparent communication during change. The result of descriptive analysis demonstrates that 67 percentages was male and 33 percentages were female. After analyzing external and internal measurement of model we conclude that authentic leader (Relational Transparency, Internalized Moral Perspective) have significant impact on trust and employees openness to 
change.

The findings suggested that authentic leader play important role, building trust cooperation coloration and credibility. Credibility brings responsibility toward employees to increase productive for the survival and existence of organization which is crucial and changing environment. The study revealed that there is no significance relationship between authentic leadership and transparent communication.

The findings also indicated that transparency in communication between leaders and subordinate lead to self-confidence and build strong and trustworthy relationship between them. The gap between leader and subordinate eradicated by ethical and transparent communication reduces the anxiety and misinformation, as it makes employee aware about organizational future. Findings also suggested that trust has strong and positive impact openness to change, to have faith in organization and action. Employee believe that change is necessary for their survival and organization in rapidly changing environment.

Further research indicated that there is positive and significant indirect relationship between authentic leader and employees openness to change. Employees desired behavior and productivity directly link with the trust level. The study also demonstrates there is strong indirect relationship between transparent communication and openness to change in mediating role of trust. Furthermore research revealed that there is weak and insignificant indirect relationship between authentic leadership and organization trust with mediating role of transparent communication,

It's the first empirical study that focus on relationship between authentic leadership , transparent communication that impact on employees openness to change and mediating role of trust. Literature is scarce regarding authentic leadership and its implication on transparent communication and organization outcome. This study focuses on how to make employees ready for change event and thus how employees can take active participation in change meanwhile how leader (authentic leader) paves the ways for change.

The result provides essential finding of practical implication. Psychological capital can be improved which includes readiness for change and relationship capital (trust). Authentic leader should inquire about the employees need and requirement and make them to participate in and inquire about their communication needs, authentic leader in organization should make an effective framework for employees get feedback of authentic leaders which leads to accountability and employees will feel involve emotionally connect with organization whereas that leads to fulfil organizational needs in rapid growing environment. Recruitment and Selection should be on competency based, give emphasis on authentic leadership characteristics and should create personal development training for authentic leadership. The result of this research add contribution emerging literature of employ openness to change, authentic leadership style transparent communication and organization trust during change it will provide practical implication of managing change.

\section{Limitation}

Firstly the research sample size do not reflect all area of Pakistan, its limited to the Karachi 
geographical region only and the research is conducted to limited industries due to focus of research to examine rapidly changing industry like (technological industries)

Secondly, change can be investigated by specific context which includes merger and acquisition partnership, leader and culture change, emerging channel of communication (social media) furthermore other leadership approach like Ethical leadership and transaction leadership can be an important factor to employees openness to change. Future research can focus on different outcome of these independent variable like sustainability, commitment and organizational citizenship behavior.

\section{References}

Ajzen, I. (1991). The theory of planned behavior. Organizational Behavior and Human Decision Processes, 50(2), 179-211. https://doi.org/10.1016/0749-5978(91)90020-T

Allen, J., Jimmiesons, N. L., Bordia, P., \& Irmer, B. E. (2007). Uncertaintyduringorganizationalchange:Managingperceptionsthroughcommunication. Journalof ChangeManagement, 7(2), 187-210. https://doi.org/10.1080/14697010701563379

Auger, G. A. (2014). Trust me, trust me not: An experimental analysis of the effect of transparency on organizations. Journal of Public Relations Research, 26, 325-343. https://doi.org/10.1080/1062726X.2014.908722

Augustsson, H., Richter, A., Hasson, H., \& von Thiele Schwarz, U. (2017). The need for dual openness to change: A longitudinal study evaluating the impact of employees' openness to organizational change content and process on intervention outcomes. The Journal of Applied Behavioral Science, 53(3), 349-368. https:// doi.org/10.1177/0021886317691930

Avolio, B. J., \& Gardner, W. L. (2005). Authentic leadership development: Getting to the root of positive forms of leadership. The Leadership Quarterly, 16(3), 315-338. https://doi.org/10.1016/j.leaqua.2005.03.001

Avolio, B. J., Gardner, W. L., Walumbwa, F. O., Luthans, F., \& May, D. R. (2004). Unlocking the mask: A look at the process by which authentic leaders impact follower attitudes and behaviors. Leadership Quarterly, 15, 801-823. https://doi.org/10.1016/j.leaqua.2004.09.003

Avolio, B. J., Walumbwa, F., \& Weber, T. (2009). Leadership: Current theories, research and future directions. Annual review of Psychology, 60, 421-449. https://doi.org/10.1146/annurev.psych.60.110707.163621

Axtell, C., Wall, T., Stride, C., Pepper, K., Clegg, C., \& Gardner, P. (2002). Familiarity breeds content: The impact of exposure to change on employee openness and well-being. Journal of Occupational and Organizational Psychology, 75(2), 217-231. https://doi.org/10.1348/09631790260098596

Balkin, J. M. (1999). How mass media simulate political transparency. Journal for Cultural Research, 3(4), 393-413. https://doi.org/10.1080/14797589909367175 


\section{Macrothink}

International Journal of Human Resource Studies ISSN 2162-3058 2020, Vol. 10, No. 3

Bamford, M., Wong, C. A., \& Laschinger, H. (2013). The influence of authentic leadership and areas of work life on work engagement of registered nurses. Journal of Nursing Management, 21, 529-540. https://doi.org/10.1111/j.1365-2834.2012.01399.x

Baron, R., \& Kenny, D. (1987). The Moderator-Mediator Variable Distinction in Social Psychological Research. Journal of personality and social psychology, 1173-1182. https://doi.org/10.1037/0022-3514.51.6.1173

Barrett, D. J. (2002). Change communication: Using strategic employee communication to facilitate major change. Corporate Communications. An International Journal, 7(4), 219-231. https://doi.org/10.1108/13563280210449804

Beck, N., Brüderl, J., \& Woywode, M. (2008). Momentum or deceleration? Theoretical and methodological reflections on the analysis of organizational change. Academy of Management Journal, 51(3), 413-435. https://doi.org/10.5465/amj.2008.32625943

Becker, J., Klein, K., \& Wetzels, M. (2012). Hierarchical latent variable models in PLS-SEM: Guidelines for using reflective-formative type models. Long Range Planning, 45(5-6), 359-394. https://doi.org/10.1016/j.lrp.2012.10.001

Beddoes-Jones, F. (2012). This relationship between AL, ethics, and trust (Authentic Leadership: The Key to Building Trust). People Management, 44-47.

Beer, M., \& Nohria, N. (2000). Breaking the code of change. Boston. Harvard Business School Press.

Bommer, W. H., Rich, G. A., \& Rubin, R. S. (2005). Changing attitudes about change: Longitudinal effects of transformational leader behavior on employee cynicism about organizational change. Journal of Organizational Behavior, 26, 733-753. https://doi.org/10.1002/job.342

Bouckenooghe, D. (2010). Positioning change recipients' attitudes toward change in the organizational change literature. The Journal of Applied Behavioral Science, 46(4), 500-531. https://doi.org/10.1177/0021886310367944

Brown, S., Gray, D., McHardy, J., \& Taylor, K. (2015). Employee trust and workplace performance. Journal of Economic Behavior \& Organization, 16(4), 361-378. https://doi.org/10.1016/j.jebo.2015.05.001

Burns, B. (2000). Managing change: A strategic approach to organizational dynamics (4th edition). Harlow: IT/Prentice-Hall.

Casimir, G., Waldman, D. A., Bartram, T., \& Yang, S. (2006). Trust and the relationship between leadership and follower performance: Opening the black box in Australia and China. Journal of Leadership and Organizational Studies, 12, 68-84. https://doi.org/10.1177/107179190601200305 


\section{Macrothink}

International Journal of Human Resource Studies

ISSN 2162-3058 2020, Vol. 10, No. 3

Černe, M., Jaklič, M., \& Škerlavaj, M. (2013). Authentic leadership, creativity, and innovation: A multilevel perspective. Leadership, 9(1), 63-85. https://doi.org/10.1177/1742715012455130

Chan, A., Hannah, S. T., \& Gardner, W. L. (2005). Veritable authentic leadership: Emergence, functioning, and impacts. Authentic Leadership Theory and Practice: Origins, Effects, and Development. Oxford: Elsevier Ltd.

Chin, W. W. (1998). The Partial Least Squares Approach to Structural Equation Modeling. In Modern Methods for Business Research. Lawrence Erlbaum Associates Publishers: Mahwah, NJ, USA, 295-336.

Chin, W., \& Marcoulides, G. (1998). The Partial Least Squares Approach to Structural Equation Modeling. Modern Methods for Business Research.

Choi, M. (2011). Employees' attitudes toward organizational change A literature review. Human Resource Management, 479-500 , 479-500. https://doi.org/10.1002/hrm.20434

Claes, F., David, F., \& Larcker. (1981). Evaluating Structural Equation Models with Unobservable Variables and Measurement Error. Journal of Marketing Research, 18(1), 39-50. https://doi.org/10.1177/002224378101800104

Clapham, S. E., Meyer, C. K., Caldwell, C., \& Proctor, G. B. (2014). Trustworthiness, Justice, and the Mediating Lens(The relationship between fairness, or justice, and trustworthiness). Journal of Business and Behavioral Sciences, 26.

Cook, K. S., \& Schilke, O. (2010). The role of public, relational and organizational trust in economic affairs. Corporate Reputation Review, 13(2), 98-109. https://doi.org/10.1057/crr.2010.14

Cotterrell, R. (1999). Transparency, mass media, ideology and community. Journal for Cultural Research, 3(4), 414-426. https://doi.org/10.1080/ 14797589909367176

Cummings, T., \& Worley, C. (2005). Cummings, T., \& Worley, C. Organizational development and change. Mason, OH: South-Western.

Currall, S. C., \& Epstein, M. J. (2003). The fragility of organizational trust: Lessons from the rise and fall of Enron. Organizational Dynamics, 32(2), 193-206. https:// doi.org/10.1016/S0090-2616(03)00018-4

Dean, J. W., Brandes, P., \& Dharwadkar, R. (1998). Organizational cynicism. Academy of Management Review, 23, 341-352. https://doi.org/10.5465/amr.1998.533230

Devos, G., Buelens, M., \& Bouckenooghe, D. (2007). Contribution of content, context, and process to understanding openness to organizational change: Two ex-perimental simulation studies. The Journal of Social Psychology, 147(6), 607-630. https://doi.org/10.3200/SOCP.147.6.607-630 
Dietz, G. (2011). Special forum essay. Going back to the source: Why do people trust each other? Journal of Trust Research, 1(2), 215-222. https://doi.org/10.1080/21515581.2011.603514

DiFonzo, N., \& Bordia, P. (1998). DiFonzo, N., \& Bordia, P. (1998). A tale of two corporations: Managing uncertainty during organizational change. Human Resource Management, 37 , 295-303. https://doi.org/10.1002/(SICI)1099-050X(199823/24)37:3/4<295::AID-HRM10>3.0.CO;2-3

Edmondson, A. (1999). Psychological safety and learning behavior in work teams. Administrative Science Quarterly, 44, 350-383. https://doi.org/10.2307/2666999

Edwards, L. (2010). Authenticity in organizational context: Fragmentation, contradiction and loss of control",. Journal of Communication Management, 14, 192-205. https://doi.org/10.1108/13632541011064481

Elving, W. J. (2005). The role of communication in organisational change. Corporate Communications: An International Journal, 10(2), 129-138. https://doi.org/10.1108/13563280510596943

Ertürk, A. (2008). A trust-based approach to promote employees' openness to organizational change in Turkey. International Journal of Manpower, 29(5), 462-483. https://doi.org/10.1108/01437720810888580

Fairhurst, G. T. (1993). Echoes of the vision: When the rest of the organization talks total quality. Management Communication Quarterly, 6(4), 331-371. https://doi.org/10.1177/0893318993006004001

Ford, J. D., \& Ford, L. W. (1995). The role of conversations in producing intentional change in organizations. Academy of Management Review, 20(3), 541-570. https://doi.org/10.5465/AMR.1995.9508080330

Fugate, M., \& Kinicki, A. J. (2008). A dispositional approach to employability: Development of a measure and test of implications for employee reactions to orga-nizational change. Journal of Occupational and Organizational Psychology, 81(3), 503-527. https://doi.org/10.1348/096317907X241579

Fugate, M., Prussia, G. E., \& Kinicki, A. J. (2012). Managing employee withdrawal during organizational change: The role of threat appraisal. Journal of Management, 38(3), 890-914. https://doi.org/10.1177/0149206309352881

Gardner, W. L., Avolio, B. L., Luthans, F., \& May, D. a. (2005). Can you see the real me?: A self-based model of authentic leader and follower development",. The Leadership Quarterly, 16, 343-372. https://doi.org/10.1016/j.leaqua.2005.03.003

Gardner, W. L., Cogliser, C. C., Davis, K. M., \& Dickens, M. P. (2011). Authentic leadership: A review of the literature and research agenda. The Leadership Quarterly, 22(6), 1120-1145. https://doi.org/10.1016/j.leaqua.2011.09.007 


\section{Ml Macrothink}

International Journal of Human Resource Studies ISSN 2162-3058 2020, Vol. 10, No. 3

George, B. (2003). Authentic leadership: Rediscovering the secrets to creating lasting value. San Francisco, CA: Jossey-Bass.

Gergs, H. H., \& Trinczek, R. (2008). Communication as the key factors to change management: A sociological perspective.In Holger Sievert, \& Daniela Bell (Eds.). Communication and leadership in the 21st century, 141-156.

Gill, R. (2002). Change management-or change leadership? Journal of Change Management, 3(4), 307-318. https://doi.org/10.1080/714023845

Hair, J F; Black, W C; Balin, B J; Anderson, R E. (2010). Multivariate data analysis. London: Maxwell Macmillan International Editions.

Hair, J. F., Hult, G. T., Ringle, C., \& Sarstedt, M. (2013). A primer on partial least squares equation modelling (PLS-SEM). London: Sage Publications.

Harter, S. (2002). Authenticity", in Snyder, C.R and Lopez, S. (Eds.), Handbook of Positive Psychology. Oxford University Press, Oxford, UK, 382-394.

Hayes, A. F. (2013). Methodology in the social sciences. Introduction to mediation, moderation, and conditional process analysis: A regression-based approach. Guilford Press.

Henseler, J; Hubona, G; Ray, P A. (2016). Using PLS Path Modeling in New Technology Research: Updated Guidelines. Ind. Manag. Data Syst. 2016. [CrossRef], 116, 2-20. https://doi.org/10.1108/IMDS-09-2015-0382

Herold, D. M., Fedor, D. B., Caldwell, S., \& Liu, Y. (2008). The effects of transformational and change leadership on employees' commitment to A change: A multilevel study. Journal of Applied Psychology, 93(2), 346-357. https://doi.org/10.1037/0021-9010.93.2.346

Herscovitch, L., \& Meyer, J. P. (2002). Commitment to organizational change: Extension of a threecomponent model. Journal of Applied Psychology, 87(3), 474.

Hon, L., \& Grunig, J. E. (1999). Guidelines for measuring relationships in public relations. Gainesville FL: Institute for Public Relations.

Hsieh, C. C., \& Wang, D. S. (2015). Does supervisor-perceived authentic leadership influence employee work engagement through employee-perceived authentic leadership and employee trust? The International Journal of Human Resource Management, 26(18), 2329-2348.

Hu, L. T., \& Bentler, P. M. (1998). Fit Indices in Covariance Structure Modeling: Sensitivity to Underparameterized Model Misspecification. Psychological Methods, 3(4), 424-453. https://doi.org/10.1037/1082-989X.3.4.424

In, K. A., \& J, S. L. (1993). Testing structural equation models. Newbury Park: Sage, 294-316.

Jan, A., \& Hazel, H. (2013). Organisational culture in knowledge creation, creativity and innovation: towards the Freiraum model. Journal of Information Science, 1-14. 
Jiang, H., \& Luo, Y. (2018). Crafting employee trust: From authenticity, transparency to engagement. Journal of Communication Management, 22(2), 138-160. https:// doi.org/10.1108/JCOM-07-2016-0055

Jiang, H., \& Men, R. L. (2017). Creating an engaged workforce: The impact of authentic leadership, transparent organizational communication, and work-life en-richment. Communication Research, 44(2), 225-243. https://doi.org/10.1177/0093650215613137

Jimmieson, N. L., Peach, M., \& White, K. M. (2008). Utilizing the theory of planned behavior to inform change management: An investigation of employee intentions to support organizational change. The Journal of Applied Behavioral Science, 44(2), 237-262. https://doi.org/10.1177/0021886307312773

Jo, S., \& Shim, S. W. (2005). Paradigm shift of employee communication: The effect of management communication on trusting relationships. Public Relations Review, 31(2), 277-280. https://doi.org/10.1016/j.pubrev.2005.02.012

Johansson, C., \& Heide, M. (2008). Speaking of change: Three communication approaches in studies of organizational change. Corporate Communications: An International Journal, 13(3), 288-305. https://doi.org/10.1108/13563280810893661

Joo, B. K., \& Nimon, K. (2014). Two of a kind? A canonical correlational study of transformational leadership and authentic leadership. European Journal of Training and Development, 38(6), 570-587.

Jung, D. L., \& Avolio, B. J. (2000). Opening the black box: An experimental investigation of the mediating effects of trust and value congruence on transformational and transactional leadership. Journal of Organizational Behavior, 21(8), 949-964. https://doi.org/10.1002/1099-1379(200012)21:8<949::AID-JOB64>3.0.CO;2-F

Kang, M., \& Sung, M. (2017). How symmetrical employee communication leads to employee engagement and positive employee communication behaviors: The mediation of employee-organization relationships. Journal of communication management, 21(1), 82-102. https://doi.org/10.1108/JCOM-04-2016-0026

Khilji, S. E., Keilson, B., Shakir, F. Y., \& Shrestha, B. K. (2015). Self,follower,organizationandthecontext -acrossculturalviewofauthenticleadership. South Asian Journal of Global Business Research, 4(1), 2-26.

Ki, E. J., \& Hon, L. C. (2007). Reliability and validity of organization-public relationship measurement and linkages among relationship indicators in a membership organization. Journalism \& Mass Communication Quarterly, 84(3), 419-438. https://doi.org/10.1177/107769900708400302

Kouzes, j., \& Posner, B. (2002). The Leadership Challenge, Jossey Bass, San Francisco, CA.

Lewis, K. L. (1997). Users' individual communicative responses to intraorganizationally implemented innovations and other planned changes. Management Communication Quarterly, 10(4), 455-490. https://doi.org/10.1177/0893318997104003 
Luo, Y., \& Jiang, H. (2014). Effective public relations leadership in organizational change: A study of multinationals in mainland China. Journal of Public Relations Research, 26(2), 134-160. https://doi.org/10.1080/1062726X.2013.864241

Luthans, F., \& Avolio, B. (2003). Authentic leadership development.Positive organizational scholarship. 241-58.

Mackey, A., \& Gass, S. M. (2015). Second language research: Methodology and design. (2. ed, Ed.) New York, NY: Routledge. https://doi.org/10.4324/9781315750606

Mayer, R. C., Davis, J. H., \& Schoorman, F. D. (1995). An integration model of organizational trust. Academy of Management Review, 20(3), 709-734. https://doi.org/ $10.2307 / 258792$

McKnight, D. H., Choudhury, V., \& Kacmar, C. (2002). Developing and validating trust measures for e-commerce: An integrative typology. Information Systems Research, 13(3), 334-359. https://doi.org/10.1287/isre.13.3.334.81

Men, L. R. (2014). Internal reputation management: The impact of authentic leadership and transparent communication. Corporate Reputation Review, 254-272. https://doi.org/10.1057/crr.2014.14

Men, L. R. (2014). Why leadership matters to internal communication: Linking transformational leadership, symmetrical communication, and employee outcomes. Journal $\begin{array}{llll}\text { of Public Relations 256-279. } & \text { Research, }\end{array}$ https://doi.org/10.1080/1062726X.2014.908719

Men, L. R. (2015). Employee engagement in relation to employee-organization relationships and internal reputation: Effects of leadership communication. Public Relations Journal, 9(2), $1-22$.

Men, L. R., \& Bowen, S. (2017). Excellence in internal communication management. New York: Business Expert Press.

Men, L. R., \& Stacks, D. (2014). The effects of authentic leadership on strategic internal communication and employee-organization relationships. Journal of Public Relations Research, 26(4), 301-324. https://doi.org/10.1080/1062726X.2014.908720

Men, L. R., \& Tsai, W. H. (2016). Public engagement with CEOs on social media: Motivations and relational outcomes. Public Relations Review, 42(5), 932-942. https://doi.org/10.1016/j.pubrev.2016.08.001.

Menguc, B., Auh, S., Fisher, M., \& Haddad, A. (2013). To be engaged or not to be engaged:The antecedents and consequences of service employee engagement. Journal of Business Research, 66(11), 2163-2170. https://doi.org/10.1016/j.jbusres.2012.01.007

Miller, V. D., Johnson, J. R., \& Grau, J. (1994). Antecedents to willingness to participate in a planned organizational change. Journal of Applied Communication Research, 22(1), 59-80. https://doi.org/10.1080/00909889409365387 
Mishra, K., Boynton, L., \& Mishra, A. (2014). Driving employee engagement: The expanded role of internal communications. International Journal of Business Communication, 51(2), 183-202. https://doi.org/10.1177/2329488414525399

Molleda, J. C. (2010). Authenticity and the construct's dimensions in public relations and communication research. Journal of Communication Management, 14, 223-236. https://doi.org/10.1108/13632541011064508

Nachmias, D. (1985). Determinants of trust with the federal bureaucracy. In D. H. Rosenbloom (Ed.), Publicpersonnelpolicy:Thepoliticsofpublicservice. PortWashington,NY:Associated Faculty, 133-143.

Neill, M. S. (2018). Change management communication: Barriers, strategies \& messaging. $\begin{array}{llll}\text { Public } & \text { Relations } & \text { Journal, } & 1,\end{array}$ https://prjournal.instituteforpr.org/wp-content/uploads/NeillMarlene_ChangeManagement.pd $\mathrm{f}$

Nielsen, K., \& Randall, R. (2013). Nielsen, K., \& Randall, R. (2013). Opening the black box: Presenting a model for evaluating organizational-level interventions. European Journal of Work and Organizational Psychology, 22(5), 601-617. https://doi.org/10.1080/1359432X.2012.690556

Oreg, S. (2006). Personality, context, and resistance to organizational change. European Journal of Work and Organizational Psychology, 15(1), 73-101. https://doi.org/ $10.1080 / 13594320500451247$

Oreg, S., Vakola, M., \& Armenakis, A. (2011). Change recipients' reactions to organizational change: A 60-year review of quantitative studies. The Journal of Applied Behavioral Science, 47(4), 461-524. https://doi.org/10.1177/0021886310396550

Paulsen, N., Callan, V. J., Ayoko, O., \& Saunders, D. (2013). TransformationalleadershipandinnovationinanR\&Dorganizationexperiencingmajorchange.

Journalof OrganizationalChangeManagement, $26(3), \quad$ 595-610. https://doi.org/10.1108/09534811311328597

Pawar, B. S., \& Eastman, K. K. (1997). The nature and implications of contextual influences on transformational leadership: A conceptual examination. Academy of Management Review, 22(1), 80-109. https://doi.org/10.5465/amr.1997.9707180260

Porras, J. I., \& Silvers, R. C. (1991). Organization development and transformation. Annual Review of Psychology, 42(1), 51-78. https://doi.org/10.1146/annurev.ps.42.020191.000411

Rawlins, B. (2008). Measuring the relationship between organizational transparency and employee trust. Public Relations Journal, 2(2), 1-21. https://doi.org/10.1080/10627260802153421

Rawlins, B. (2009). Give the emperor a mirror: Toward developing a stakeholder measurement of organizational transparency. Journal of Public Relations Research, 21(1), 71-99. https://doi.org/10.1080/10627260802153421 


\section{Macrothink}

International Journal of Human Resource Studies ISSN 2162-3058 2020, Vol. 10, No. 3

Reichers, A. E., Wanous, J. P., \& Austin, J. T. (1997). Understanding and managing cynicism about organizational change. Academy of Management Executive, 11, 48-59. https://doi.org/10.5465/ame.1997.9707100659

Rotter, J. B. (1967). A new scale for the measurement of interpersonal trust. Journal of Personality, 35(4), 651-665. https://doi.org/10.1111/j.1467-6494.1967

Rousseau, D. M., \& Tijoriwala, S. A. (1999). What's a good reason to change? Motivated reasoning and social accounts in promoting organizational change. Journal of Applied Psychology, 84(4), 514-528. https://doi.org/10.1037/0021-9010.84.4.514

Rousseau, D. M., Sitkin, S. B., Burt, R. S., \& Camerer, C. (1998). Not so different after all: A cross-discipline view of trust. Academy of Management Review, 23, 393-404. https://doi.org/10.5465/amr.1998.926617

Saks, A M;. (2006). Antecedents and consequences of employee engagement. Journal of Managerial Psychology, 21(7), 600-618.

Schoorman, F. D., Mayer, R. C., \& Davis, J. H. (2007). An integrative model of organizational trust: Past, present, and future. Academy of Management Review, 32(2), 344-354. https://doi.org/10.5465/AMR.2007.24348410

Seeger, M. W., Ulmer, R. R., Novak, J. M., \& Sellnow, T. (2005). Post-crisis discourse and organizational change, failure and renewal. Journal of Organizational Change Management, 18(1), 78-95. https://doi.org/10.1108/09534810510579869

Shapira-Lishchinsky, O., \& Tsemach, S. (2014). Psychological empowerment as a mediator between teachers' perceptions of authentic leadership and their withdrawal and citizenship behaviors. Educational Administration Quarterly, 50(4), 675-712. https://doi.org/10.1177/0013161X13513898

Shin, J., Taylor, M. S., \& Seo, M. G. (2012). Resources for change: The relationships of organizational inducements and psychological resilience to employees' attitudes and behaviors toward organizational change. Academy of Management Journal, 55, 727-748. https://doi.org/10.5465/amj.2010.0325

Shockley-Zalabak, p., \& Ellis, k. (2006). The communication of trust. In T. L. Gillis (Ed.). The IABC handbook of organizational communication, 44-55.

Showry, M., \& Manasa, K. V. (2014). Self-Awareness - Key to Effective Leadership. IUP Journal of Soft Skills, 8, 15-26.

Shrout, P. E., \& Bolger, N. (2002). Mediation in experimental and nonexperimental studies: New procedures and recommendations. Psychological Methods, 7(4), 422-445. https://doi.org/10.1037/1082-989X.7.4.422

Spoelstra, S., Butler, N., \& Delaney, H. (2016). Never let an academic crisis go to waste. Leadership studies in the wake of journal retractions. Leadership, 12(4), 383-397. 
Stanley, D. J., Meyer, J. P., \& Topolnytsky, L. (2005). Employee cynicism and resistance to organizational change. Journal of Business and Psychology, 19, 429-459. https://doi.org/10.1007/s10869-005-4518-2

Tan, H. H., \& Tan, C. S. (2000). Toward the differentiation of trust in supervisor and trust in organization. Genetic, Social, and General Psychology Monographs, 126(2), 241-260.

Tongco, M. D. (2007). Purposive sampling as a tool for informant selection. Ethnobotany Research and Applications, 5(1), 147-158. https://doi.org/10.17348/era.5.0.147-158

Valsania, S. E., León, J. A., Alonso, F. M., \& Cantisano, G. T. (2012). Authentic leadershipand its effect on employees' organizational citizenship behaviours", Psicothema. 24(4), 561-566.

Vathsala, W., \& Ruvini, W. (2012). Effects of interpersonal trust, team leader support, rewards, and knowledge sharing mechanisms on knowledge sharing in project teams. VINE, 42(2), 214 - 236. https://doi.org/10.1108/03055721211227255

Waldo, D. (1977). Developments in public administration. In A. Altschuler \& N. Thomas (Eds.), The politics of the federal bureaucracy. New York: Harper \& Row., 17-36.

Walumbwa, F. O., Avolio, B. J., Gardner, W. L., \& Wernsing, T. a. (2008). Authentic leadership: Development and validation of a theory-based measure. Journal of Management, 34, 89-126. https://doi.org/10.1177/0149206307308913

Walumbwa, F. O., Wang, P., Wang, H., Schaubroeck, J., \& Avolio, B. J. (2010). Psychological processes linking authentic leadership to follower behaviors. The Leadership Quarterly, 21(5), 901-914. https://doi.org/10.1016/j.leaqua.2010.07.015

Wanberg, C. R., \& Banas, J. T. (2000). Predictors and outcomes of openness to changes in a reorganizing workplace. Journal of Applied Psychology, 85(1), 132-142. https://doi.org/10.1037/0021-9010.85.1.132

Woolley, L., Caza, A., \& Levy, L. (2011). Authentic leadership and follower development: Psychological capital, positive work climate, and gender. Journal of Leadership \& Organizational Studies, 18, 438-448. https://doi.org/10.1177/1548051810382013

Yang, S U. (2007). An integrated model for organization-Public relational outcomes, organizational reputation, and their antecedents. Journal of Public Relations Research, 19(2)(91-121). https://doi.org/10.1080/10627260701290612

Yang, U. S., \& Lim, J. S. (2009). The effects of blog-mediated public relations (BMPR) on relational trust. Journal of Public Relations Research, 21(3), 341-359. https://doi.org/10.1080/10627260802640773

Yue, C. A., Men, L. R., \& Ferguson, M. A. (2019). Bridging transformational leadership, transparent communication, and employee openness to change: The mediating role of trust. Public Relations Review, 45(3), 101779. https://doi.org/10.1016/j.pubrev.2019.04.012 


\section{Macrothink}

International Journal of Human Resource Studies

ISSN 2162-3058 2020, Vol. 10, No. 3

Yukl, G. (2006). Leadership in organizations, Sixth edition, Upper Saddle River, NJ: Prentice Hall.

\section{Copyright Disclaimer}

Copyright for this article is retained by the author(s), with first publication rights granted to the journal.

This is an open-access article distributed under the terms and conditions of the Creative Commons Attribution license (http://creativecommons.org/licenses/by/4.0/). 